Georgetown University Law Center

Scholarship @ GEORGETOWN LAW

2001

\title{
Aha? Is Creativity Possible in Legal Problem Solving and Teachable in Legal Education?
}

Carrie Menkel-Meadow

Georgetown University Law Center, meadow@law.georgetown.edu

This paper can be downloaded free of charge from:

https://scholarship.law.georgetown.edu/facpub/177

6 Harv. Negot. L. Rev. 97-144 (2001)

This open-access article is brought to you by the Georgetown Law Library. Posted with permission of the author. Follow this and additional works at: https://scholarship.law.georgetown.edu/facpub

Part of the Dispute Resolution and Arbitration Commons, and the Legal Education Commons 


\section{GEORGETOWN LAW Faculty Publications}

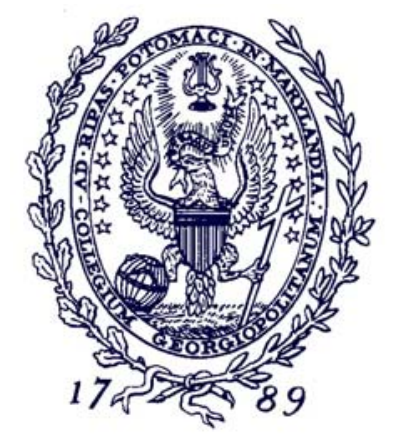

January 2010

\section{Aha? Is Creativity Possible in Legal Problem Solving and Teachable in Legal Education?}

6 Harv. Negot. L. Rev. 97-144 (2001)

\section{Carrie Menkel-Meadow \\ Professor of Law \\ Georgetown University Law Center meadow@law.georgetown.edu}

This paper can be downloaded without charge from:

Scholarly Commons: http://scholarship.law.georgetown.edu/facpub/177/

Posted with permission of the author 


\title{
Aha? Is Creativity Possible in Legal Problem Solving and Teachable in Legal Education?
}

\author{
Carrie Menkel-Meadow†
}

Editor's Note: On April 7 \& 8, 2000, the Harvard Negotiation Law Review and the Program on Negotiation at Harvard Law School hosted "The Lawyer as Problem Solver: Dispute Resolution and Deal Making." A series of panels addressed aspects of problem solving as an approach to lawyering and in particular the relationship between problem solving and negotiation. Prof. Menkel-Meadow was the principal presenter at the "Problem Solving and Legal Education" panel, where she presented an earlier version of this paper. The Harvard Negotiation Law Review wishes to thank Prof. Menkel-Meadow for her important contribution to the success of the symposium, and for agreeing to let us publish this thought-provoking article.

\section{INTRODUCTION}

\section{A. Problem-Solving, Negotiation and Creativity}

In the recent re-introduction of his book Local Knowledge, ${ }^{1}$ Clifford Geertz remarked, "it is hard to decide which is the more difficult task: starting a line of thought, or sustaining one." In many respects, I, too, have felt this difficulty acutely. I began talking about legal problem solving in the 1970 s, while attempting to reframe the

$\doteqdot$ @ 2000 Carrie Menkel-Meadow. Professor of Law, Georgetown University Law Center; Chair, CPR Institute for Dispute Resolution-Georgetown Commission on Ethics and Standards in ADR; Visiting Professor, Harvard Law School, 2001. Thanks to my colleagues at Georgetown for indulging my questions and conversations about legal creativity and problem solving and special thanks to Robert Meadow and Richard Diamond-two of the most creative problem solvers I know. Thanks also to Meredith Weinberg, research assistant and editor extraordinaire. The ideas in this paper have been presented to a variety of scholars and practitioners at Harvard, Stanford, Georgetown, Osgoode Hall, CLE programs and in negotiation training programs in several different countries. I appreciate the good will and reactions of those audiences who demonstrated a wide range of creative reactions.

1. Clifford Geertz, Local KNowledge: Further Essays in Interpretive As. THROPOLOGY (3d ed. 2000).

2. Id. at ix. 
way lawyers approached legal negotiations, suggesting that a different mind-set, orientation or framework, which I called problem-solving, would produce both better outcomes and processes than the more conventional, adversarial approach to legal negotiations. ${ }^{3}$ I offered the following definition:

[The] problem solving model seeks to demonstrate how negotiators, on behalf of litigators or planners, can more effectively accomplish their goals by focusing on the parties' actual objectives and creatively attempting to satisfy the needs of both parties, rather than by focusing exclusively on the assumed objectives of maximizing individual gain (emphasis added). 4

This definition and the article in which it appeared suggested that legal negotiation, as a form of social problem solving, could be taught and learned. In addition to suggesting a structured way of analyzing clients' and parties' needs, interests and objectives, the problem solving approach to negotiation argued that lawyers could be more creative (and less bound by precedent and traditional boilerplate) in the solutions they sought for legal problems and transactions. In the last twenty years we have come a long way in the teaching and practice of negotiation in law schools, law offices and other legal institutions. At the same time, we still have a long way to go in the conceptualization and operationalizing of teaching all the elements of good legal problem solving and judgment, including the "creation" of solutions to legal problems. Where do good, interesting, creative and workable solutions to legal problems come from? Can law students, lawyers, clients and other legal actors be taught to frame legal problems effectively and to seek innovative and implementable solutions? Are solutions to legal problems to be found exclusively within the currently existing domain of legal resolutions (cases and settlements) or boilerplate clauses?

This article continues and expands on my earlier project of seeking to describe how legal negotiation should be understood conceptually and undertaken behaviorally to produce better solutions to legal problems. As structured problem solving requires interests, needs and objectives identification, so too must creative solution seeking have its structure and elements in order to be effectively

3. See Carrie Menkel-Meadow, Legal Negotiation: A Study of Strategies in Search of a Theory, 1983 AM. B. Found. RES. J. 905; Carrie Menkel-Meadow, Toward Another View of Legal Negotiation: The Structure of Problem Solving, 31 UCLA L. Rev. 754 (1984).

4. Menkel-Meadow, Toward Another View of Legal Negotiation, supra note 3, at 758. 
taught. Because research and teaching about creativity and how we think has expanded greatly since modern legal negotiation theory has been developed, it is now especially appropriate to examine how we might harness this new learning to how we might examine and teach legal creativity in the context of legal negotiation and problem solving. This article explores both the cognitive and behavioral dimensions of legal creativity and offers suggestions for how it can be taught more effectively in legal education, both within the more narrow curricula of negotiation courses and more generally throughout legal education.

This article explores some of the cognitive processes that can produce good, better or even wise solutions to legal problems. How exactly do we think to solve problems?5 At some point the cognitive processes in most legal problems become social processes as well, since negotiated problem solving means working with at least one other person, and usually more than one. Therefore, thinking and communicating with others will be required as well. This article suggests that there is not only one way to think like a lawyer. Good problem solving requires many modes of thinking, in which legal, analytic and analogical thinking are a part, but not the whole, of what we need. ${ }^{6}$ This article also translates work from a variety of other disciplines that have focused on thinking and problem solving, and explicates how we can teach imaginative thinking in the context of

5. Some recent analysts of lawyer problem solving have focused on individual levels of problem solving or decision making. See, e.g., Gary Blasi, What Lawyers Know: Lawyering Expertise, Cognitive Science and the Functions of Theory, 45 J. LEG. ED. 313 (1995); Graham Strong, The Lawyer's Left Hand: Nonanalytical Thought in the Practice of Law, 69 U. Colo. L. REv. 759 (1998). Others are beginning to explore the complexities of multi-party problem solving and decision making and how those more social processes might differ from individual problem solving. See, e.g., Paul Brest \& Linda Krieger, Lawyers as Problem Solvers, 72 Texip. L. Rev. 811 (1999); Gary Goodpaster, Coalitions and Representative Bargaining, 9 Ono Sr. J. Disp. Res. 243 (1994); Russell Korobkin \& Chris Guthrie, Psychology, Economics and Settlement: A New Look at the Role of the Lawyer, 76 TEx. L. REv. 77 (1997). For an application of how unilateral versus bilateral problem solving (defined as risk and cost minimization) should be mapped onto substantive legal doctrines, see Howard Latin, Problem Solving Behavior and Theories of Tort Liability, 73 CAL. L. Rev. 677 (1985).

6. The Carnegie Foundation for the Advancement of Teaching is currently undertaking a study of professional education, including law, in which it examines the multiple epistemologies of thinking like a lawyer, taught in law schools, which includes a problem solving approach to legal education. See Announcement of Carnegie Preparation for the Professions Program, 1999, at http:/www.carnegiefoundation.org/ whatsnew (last visited Feb. 9, 2001). 
creatively solving and negotiating legal problems, transactions, matters or events. ${ }^{7}$

This article begins with a review of problem solving in the negotiation context and what forms of cognition, decision making, knowledge and capacities we might need to solve legal problems (Part II). Next, the article explores the role of research and study of creativity and its relationship to problem solving or legal cultural production (Part III). Then, the article briefly reviews the work of several psychologists who have focused on creativity, ${ }^{8}$ decision making, ${ }^{9}$ multiple intelligences, ${ }^{10}$ and cognition ${ }^{11}$ as theoretical and empirical objects of study. ${ }^{12}$ This section also reviews practical "how-to" literature, ${ }^{13}$ which draws on more intellectually rigorous work, and attempts to teach creativity by broadening the way people define problems and extends the universe from which they seek solutions. This article then turns to the challenge of applying this work to legal problem solving (Part IV). What does it mean to speak of legal creativity? What is legal creativity? How does it solve problems? Can it

7. I want to emphasize the point that many people do not have legal problems, instead they are engaged in completing a transaction, seeking legal advice about possible courses of action, or may be engaged in a legal event which may or may not even be deemed problematic (home purchase, adoption of child). See Carrie MenkelMeadow, The 59th Street Legal Clinic: Evaluation of the Experiment 40 (1979).

8. See, e.g., Teresa M. Amabile, Creativity in Context (1996); Mihaly Csik. Szentmihalyi, Creativity: Flow and the Psychology of Discovery and Invention (1996); Dimensions of Creativity (Margaret Boden ed., 1996); Handbook of CreaTIVITY (Robert J. Sternberg ed., 1999).

9. See, e.g., Gary Klein, Sources of Power: How People Make Decisions (1998); James REASON, Human ERror (1990).

10. See Howard Gardner, Frames of Mind: The Theory of Multiple IntelliGENCES (1983).

11. See Daniel Kahneman, Paul Slovic \& Amos Tversky, Judgment Under UnCERTAinty: Heuristics AND Biases (1982); Richard NisbetT \& LeE Ross, Human INFERENCE: STRATEgIES ANd SHortComings OF Social JudGMENT (1980).

12. This paper will not discuss the problem solving literature in engineering, architecture, psychiatry and social work, to mention a few other domains in which these issues have been explored.

13. See, e.g., James Adams, Conceptual Blockbusting: A Guide to Better Ideas (1986); James Adams, The Care and Feeding of Ideas: A Guide to Encouraging Creativity (1986); Edward de Bono, Lateral Thinking: Creativity Step by Step (1990); Martin GardNER, aha! Insight (1978); Martin Gardner, AHA! Gotchia: Paradoxes to Puzzle and Delight (1982); Floyd Hurt, Rousing Creativity: Think New Now! (1999); Gerard I. Nierenberg, The Art of Creattive Thinking (1982); Donald J. Noone, Creative Problem Solving (1998); Robert W. Olson, The Art of Creative Thinking: A Practical Guide (1978); Vincent Ryan Ruggiero, The Art of Thinking: A Guide to Critical and Creattve Thought (5th ed.1998); see also Richard S. Blackburn, Managing Creativity in Academics, in MANAGing in ACADEMics: A Health Center Model (Jill Ridky \& George F. Sheldon eds., 1993); Jennifer James, Thinking in the Future Tense: A Workout for the Mind (1997). 
be taught? Finally, the article explores the methods of teaching about creativity in legal education (Part V). Can it be done? How?

\section{B. A Brief Review of Legal Problem Solving Negotiation Theory}

Problem solving negotiation theory has suggested several departures from conventional negotiation theory and practice: (1) that parties might have actual needs, goals or objectives that are different than those assumed to be true by their lawyer-representatives in the negotiation; (2) that a focus on all ${ }^{14}$ parties' needs, goals and objectives (rather than an assumed goal of individual maximization) might produce better outcomes (producing some form of joint gain) and (3) that negotiators should seek creatively to meet the needs ${ }^{15}$ of the parties, and thus explore new, as well as precedented, solutions to party issues.

Fisher \& Ury's Getting to Yes (1981), Howard Raiffa's The Art and Science of Negotiation (1982) and David Lax and James Sebenius' The Manager as Negotiator: Bargaining for Cooperation and Competitive Gain (1986), demonstrate the intellectual convergence of the time, revealing a shift that was occurring in the underlying culture. The negotiation field was transforming to include more disciplinary domains, including law, business, anthropology, political science, international relations and diplomacy, psychology, sociology and economics. Some transdisciplinary fields also illuminated problems to be solved in understanding negotiation behavior, for instance, game theory, ${ }^{16}$ decision theory, ${ }^{17}$ rational choice theory, ${ }^{18}$

14. For my argument that many, if not most, legal problems today involve more than two parties and so require a multi-party inventory of needs, goals and objectives, see Carrie Menkel-Meadow, The Trouble with the Adversary System in a Post-Modern, Multi-Cultural World, 38 WM. \& MARY L. Rev. 5 (1996). Lon Fuller recognized this aspect of some legal problems in Mediation: Its Form and Its Functions, $44 \mathrm{~S}$. CAL. L. REv. 305 (1971).

15. For a discussion of why I used the term "needs," in addition to the "interests" or "objectives" used by other negotiation theorists, see infra note 52 and accompanying text.

16. See, e.g., Robert Axelrod, The Complentry of Cooperntion: Agent Based Models of Competition and Collaboration (1997); Robert ANelrod, The Evolu. tion of Cooperation (1984); Douglas Baird et. al., Game Theory and thie Lay (1994); AdaM M. Brandenburger \& Barry Nalebuff, Co-opetition (1996); Avinash Dixit \& Barry Nalebuff, Thinkmng Strategically: The Competitive Edge in Business, Politics and Everyday Life (1991); William Poundstone, Prisoner's Di. LEMTMA (1992).

17. See, e.g., Max Bazerman, Judgment in Managerlal Decision Maring (4th ed. 1998); John Hammond, Ralph Keeney \& Howard Raiffa, Summ Choices: A Practical Guide to Making Better Decisions (1999); Gary Klein, Sources of 
democratic discourse theory, ${ }^{19}$ organizational development, ${ }^{20}$ and systems theory and conflict theory. ${ }^{21}$ The negotiation field now includes basic ideas that are taught in a variety of different contexts, including law schools, business schools, policy and planning schools, international relations programs, economics and psychology departments and even some free standing conflict resolution programs. ${ }^{22}$

Despite the existence of some key concepts that cross disciplines, there are other dimensions of the negotiation field that are particularly dependent on the specific domain in which negotiation problems occur. The core concepts that cross disciplinary boundaries include differences between creating and claiming value (or integrative and distributive bargaining); the importance of separating inventing from evaluating (creativity and synthesis before critique and analysis); the recognition of complementary, ${ }^{23}$ rather than conflicting, needs and interests for trades; the significance of distinguishing underlying needs and interests from positions to get at root causes; the acknowledgment of concern for others, as well as self; and finally, the complexities of strategic and dynamic, rather than static, behavioral and

Power: How People Make Decisions (1998); J. Edward Russo \& Paul J. H. Shoemaker, Decision Traps: Ten Barriers to Brilliant Decision-Making and How to OVERCOME THEM (1989).

18. See, e.g., Kenneth Arrow, Social Choice and Individual Values (1951); Russell Hardin, Collective Action (1982); Mancur Olson, The logic of Collective Action: Public Goods and the Theory of Groups (1965); $c f$. Donald Green \& Ian Shapiro, Pathologies of Rational Choice Theory: A Critique of Applications in Political Science (1994).

19. See, e.g., James Bohman, Public Deliberation: Pluralism, Complexity and Democracy (1996); Deliberative Politics: Essays on Democracy and Disagreement (Stephen Macedo ed., 1999); Amy Gutmann \& Dennis Thompson, Democracy and Disagreement (1996); Jurgen Habermas, The Theory of Communicative ACtion (Vol. 1, 1984 \& Vol. 2, 1987); Jane J. Mansbridge, Beyond Adversary Democ. RACY (1980).

20. See, e.g., James G. March \& Herbert A. Simon, Organizations (1958); Diane Vaughan, Rational Choice, Situated Action and the Social Control of Organizations, 32 L. \& Soc'y Rev. 23 (1998); see also Diane Vaughan, The Challenger Launch Decision: Risky Technology, Culture and Deviance at NASA (1996).

21. See, e.g., Conflict, CoOperation AND Justice: ESSAys INSPIRED BY THE Work of Morton Deutsch (Barbara Benedict Bunker et al. eds., 1995); Lewis A. Coser, The Functions of Social Conflict (1956); Morton Deutsch, The Resolution of Conflict: Constructive and Destructive Processes (1973); Dean G. Pruitr \& Jef. frey Z. Rubin, Social Conflict: Escalation, Stalemate, and Settlement (1986); Marc Howard Ross, The Management of Conflict: Interpretations and Interests in Comparative Perspective (1993); Thomas C. Schelling, The Strategy of Conflict (1960); Georg Simmel, Conflict (1955).

22. See Program On Negotiation, Negotiation Pedagogy: A Research Survey of Four Disciplines, at http://www.pon.harvard.edu/events/hewlett/day1/shtml (last visited Feb. 9, 2001).

23. See George Homans, Social Behavior: Its Elementary Forms (1974). 
substantive situations. ${ }^{24}$ Legal negotiators, must, however, also be concerned with the role of law in solving problems, ${ }^{25}$ the difficulties of multi-party negotiations when one serves as an agent for another, ${ }^{26}$ the need for precedent and publicly announced rules, ${ }^{27}$ the differentiated incentives of different fee arrangements, ${ }^{28}$ and the specialized and rule-based ethical system in which lawyer negotiators must operate. ${ }^{29}$ At a deeper level, some argue that lawyer negotiators have an obligation to do justice, ${ }^{30}$ not just to accomplish legally permissible, rule-based or Pareto-optimal results.

Thus, creatively solving problems in the legal domain implicates the development of creative faculties, exercised within some constraints of law and legal principle. The creative legal problem solver, then, must learn to navigate within the seas of optimistic creativity, the swells of dynamic interaction with others (client and other counsel and parties) and the oceans of realistic legal possibility. We begin with an explication of the negotiation process as a structured problem solving exercise, in which party needs are identified to suggest opportunities for both individual and joint gain.

24. See, e.g., Lee Ross \& Richard E. Nisbett, The Person and the Situation: Perspectives of Soclal Psychology (1991).

25. See Robert Mnookin \& Lewis Kornhauser, Bargaining in the Shadow of the Law: The Case of Divorce, 88 YALE L.J. 950 (1979).

26. See Robert Mnookin, Scott R. Peppet, Andrew S. Tulumello, Beyond Winning: Negotiating to Create Value in Deals and Disputes (2000); Robert Mnookin, Why Negotiations Fail: An Exploration of Barriers to the Resolution of Conflict, 8 OHio St. J. Disp. Resol. 235 (1993).

27. See David Luban, Settlements and the Erosion of the Public Realm, 83 Gro. L.J. 2619 (1995).

28. See, e.g., Herbert M. Kritzer, Let's Make a Deal: Understanding the Ne. gotiation Process in ORdinary Litigation (1991); Herbert M. Kritzer, Fee Arrangements and Negotiations: A Research Note, 21 L. \& Soc'y REv. 341 (1987) (arguing that Menkel-Meadow's "creative solutions" to legal negotiation problems will be unlikely where lawyers are paid on a contingent basis).

29. See, e.g., James J. White, Machiavelli and the Bar: Ethical Limitations on Lying in Negotiation, 1980 AM. B. Found. Res. J. 926; cf. Eleanor Holmes Norton, Bargaining and the Ethic of Process, 64 N.Y.U. L. REv. 493 (1989); Murray Schwartz, The Professionalism and Accountability of Lawyers, 66 CAL. L. REv. 669 (1978); Gerald Wetlaufer, The Ethics of Lying in Negotiations, 75 Iowa L. Rev. 1219 (1990).

30. See, e.g., Robert Condlin, "Cases on Both Sides": Patterns of Argument in Le. gal Dispute-Negotiation, 44 MD. L. REv. 65 (1985); Owen M. Fiss, Against Settlement, 93 YaLe L.J. 1073 (1984); cf. Carrie Menkel-Neadow, Whose Dispute Is It Anyway? A Philosophical and Democratic Defense of Settlement (In Some Cases), 83 GEo. L.J. 2663 (1995) (arguing that in order to do justice, sometimes legal negotiators must resolve issues outside the law, with particularized solutions for the parties). 


\section{The Legal Negotiator as Problem Solver}

Most of the work comprising the new canon in negotiation theory and practice is directed to the same ends-better solutions for the parties which cause the least harm to the parties involved, and where possible, those who might be affected by any negotiated solution. Whether labeled a "wise, fair and efficient" solution, ${ }^{31}$ a Pareto-optimal solution or a superior solution or even a "win-win" solution, ${ }^{32}$ modern negotiation theorists and practitioners view "problem solving" or "principled" or "interest-based" negotiation" ${ }^{33}$ as a way to achieve better outcomes. Such theorists and practitioners believe that these solutions can be arrived at through different orienting frames, rather than default assumptions of competition over scarce resources or through adjudicated or arbitrated solutions in which one party wins and the other loses. Even if binary solutions are appropriate in some matters, the complexity of some problems, the existence of multiple parties, on going relations, the need for flexibility and the opportunity to control the terms of resolution suggest that party negotiations will often provide an opportunity for more tailored and responsive solutions in many legal matters. ${ }^{34}$

Where are those solutions to come from? Negotiation literature has developed a set of prescriptions and descriptions for both enhancing and decreasing the likelihood of achieving desirable solutions. Some of these prescriptions focus on behavioral suggestions, while others emphasize analytic suggestions. Negotiators are urged to explore and invent "options for mutual gain," 35 taught to seek to expand

31. Roger Fisher, William Ury \& Bruce Patton, Getting to Yes: Negotiation Agreement Without Giving In, 4 (1991).

32. See Steven J. Brams \& Alan D. Taylor, The Win-Win Solution: Guaran. TEEING Fair Shares to Everybody (1999). I prefer to stay away from the win-win nomenclature in legal disputes. Often in legal matters someone will not be able to win anything-a criminal defendant who engages in plea negotiations but who will serve jail time; a manufacturer of a defective product who will have to take the product off the market and perhaps pay millions of dollars in damages. These are not winning solutions to the legal problem at hand, but the negotiated outcome may still be better than what might have occurred without negotiation (more transaction costs, more pay-outs, more embarrassment, adverse publicity or emotional pain).

33. Menkel-Meadow, Toward Another View of Negotiation, supra note 3.

34. In jurisprudential terms, we can see this as the development of responsive or participatory law out of the earlier states of command, repression and individual maximization or autonomous law. See Phillippe Nonet \& Philip Selznick, Law and So. CIETY In TRansition: Toward Responsive Law (1978).

35. See Fisher \& Ury, supra note 31 , at 56-80. 
pies before dividing them, or "create value before claiming it," couraged to brainstorm and invent before evaluating, and pushed to look behind stated preferences or positions to find underlying needs and interests and search for principles or "objective criteria"37 to resolve that which cannot be resolved by mutually acceptable trades. Negotiation teaching has moved to increasingly demanding planning exercises that require students to analyze a wide variety of party needs, preferences, desires, objectives, possible legal outcomes, cost benefit analysis, decision tree analysis, ${ }^{38}$ best-case/worst-case scenarios, and contingency plans that are designed to force negotiators to analyze the substance of their dispute before they even sit down to talk to the other side. Negotiation analysis, before any behavior with the other side is even enacted, requires rigorous thinking, planning for problem identification, fact-finding, legal research, option generation, brainstorming, strategies for communication, information sharing, persuasion of other parties and consideration of agreement implementation and execution. ${ }^{39}$

Once the needs, interests, objectives and goals of all interested parties have been identified, facts have been investigated and agendas for information sharing have been developed, where do particular solutions to legal matters or problems come from? Is there any systematic way to develop substantive solutions to negotiated legal problems? How do lawyers generate options, find alternative courses

36. See Lax \& Sebenius, The Manager as Negotiator: Bargaining for Cooperation and Competitive Gain, (1986); MINOOKIN ET AL, BEYOND WINNING, supra note 26.

37. See Fisher \& Ury, supra note 31, at 81-94.

38. See, e.g., Marjorie Corman Aaron, Decision Analysis, in MIedhating LegnL Disputes: Effective Strategies for Lawyers and Mediators (Dwight Golann ed., 1996); Hammond, supra note 17. See also Bert Useem et al., Resolution of Prison Riots, NIJ RESEARCH IN BRIEF, 1995, at www.soci.niu.edu/-critcrim/escapes/prisriot.txt (last visited February 18, 2001) (suggesting difference between "proactive planning and "reactive problem-solving" in prison riot negotiation).

39. For examples of these planning processes, see Carrie Menkel-Meadow, NEGotiation Plans for Dispute Resolution (litigation) Probleas and Business Plas. Ning or Transactional Planning (1990); Roger Fisher \& Danni Ertel, Getring Ready to Negotiate: The Getting to Yes Workbook (1995). Such planning documents reflect an attention to the stages and phases of most negotiations and thus represent an operationalization of the theorized structure of negotiations as described by both negotiation theorists and empiricists. See, e.g., P. H. GuLlivER, DispUTES AND Negotiations: A Cross Cultural Perspective (1979); Carrie Menkel-Meadow, Stages and Phases of Negotiation, in David Binder \& Carrae Mienkel-Meadow, Amierican Bar Association Lawyering Skills Institute (1982); Leigh Thosipson, The Mind and Heart of the Negotiator (1998); Gerald Willinas, Legal Negoth. TION AND SETTLEMENT (2000). 
of action, consider potential or alternative clauses ${ }^{40}$ in documents and deals, discover sources of financing, create rules of deal or organizational governance, risk allocation, profit allocation, admissions of wrongdoing, compensation, policy changes and the literally dozens of legal "tropes" or solutions that constitute legal problems?

Dispute negotiation too often looks for its solutions among the legal precedents or outcomes thought likely in the "shadow of the courthouse" (these days most often compromise of some monetary values), and deal negotiations too often seek solutions in the boilerplate language of form contracts for transactions. ${ }^{41}$ Ironically, these litigated outcomes and boilerplate clauses were once the creative ideas of some lawyers who developed a new reading of a statute, a novel argument before a common law or Constitutional court, developed a new scheme of risk allocation, or found a new source of capital or drafted a new clause for a deal document.

Solutions to legal problems, then, come from creative lawyers, as well as legal or practice precedent. The challenge for negotiation theorists, practitioners and teachers is to find systematic ways to teach solution devising, short of reading thousands of cases, transactional documents, statutes or other legal documents that will show us not only what already has been done, but also what might be done. Are there ways of learning or thinking about solutions to legal problems that are generic or are there only substantive (domain based) solutions? Here the teachings of other disciplines may be useful. Some researchers focus on the positive solution-seeking side of cognition and creativity; others focus on the negative side of impediments to good or, as they define it, rational decision making or problem solving.

Social and cognitive psychologists have been mapping decision processes in a variety of situations in which decision makers have to act under uncertainty. Thanks to the pathbreaking work of such scholars as Amos Tversky, Daniel Kahneman, Lee Ross, Robert Nisbett and others, we know a variety of ways in which negotiators use distorted thinking processes or make human errors. Some of the errors which have been identified are particularly salient for legal decision making. The common process of reactive devaluation, for

40. See Marcel Kahan \& Michael Klausner, Standardization and Innovation in Corporate Contracting (Or "The Economics of Boilerplate"), 83 VA. L. REv. 713 (1997). 789.

41. See Menkel-Meadow, Toward Another View of Negotiation, supra note 3, at 
example, suggests that we do not accurately process offers or information given to us from a party to which we feel adverse. ${ }^{42}$ Most relevant to legal negotiators, parties tend to have overconfidence in their own positions, ${ }^{43}$ which can cause great distortions in conventional monetary allocative negotiations. As humans, we are all subject to certain informational or heuristic biases, like primacy, recency, dramatic and anchoring effects of heard numbers, events or arguments. As a result, we commit statistical or probabilistic errors. Some of our errors in reasoning are differentially distributed-some of us are greater gamblers than others and fear losses or take risks more or less often than others. Almost all of us value what we already have more than what we might receive in the future (a result familiar to any negotiation teacher who uses bidding game exercises).

Sociologists and social psychologists have also demonstrated that problem solving can sometimes be enhanced, and other times hindered, by being conducted in group settings. While there is some evaluation research that supports better quality, as well as quantity, of solutions in brainstorming sessions, ${ }^{44}$ there is also the problem of groupthink ${ }^{45}$ or organizational impediments to taking responsibility that can distort problem solving with multiple actors. ${ }^{46}$ And, controversial though it might be, there is some evidence of gender, racial, ethnic and cultural differences in negotiated outcomes and behaviors. ${ }^{47}$ For example, attribution theory tells us that women are more

42. See Lee Ross, Reactive Devaluation in Negotiation and Conflict Resolution, in Barriers to Conflict Resolution (Kenneth J. Arrow et al. eds., 1995). In addition to the opposite side of a legal case, this can include one's parent, child, spouse, boss or employee, or anyone who is not of our point of view.

43. See Shelley E. TAylor, Positive Illusions (1989); Shelley Taylor \& J. Brown, Illusion and Well Being: A Social Psychological Perspective on Mental Health, 103 Psych. Bull. 193 (1988).

44. See Amabile, supra note 8, at 244-45; R.M. Milgram \& N.A. Milgram, Group vs. Individual Administration in the Measurement of Creative Thinking in Gifted and Non-gifted Children, 49 CHILD DEv. 385 (1978).

45. See Richard Cialdini, Influence: The Psychology of Persuasion (1984); Irving Janis, Groupthink: Psychological Studies of Policy Decisions and Fins$\cos (1983)$.

46. See Wendy M. Williams \& Lana T. Yang, Organizational Creativity, in Hand. BOOK OF CREATIVITY (Robert J. Sternberg ed., 1999); Donald Langevoort, Behavioral Theories of Judgment and Decision Making in Legal Scholarship: A Literature Review, 51 VAND. L. REv. 1499 (1998); David Luban, Milgram Re-visited, 9 Researching LAW: AN ABF Update, SPRING 1998.

47. See Jeffrey Rubin \& Bert Brown, The Soclal. Psychology of Bargannisg and Negotiation (1975); Ian Ayres, Fair Driving: Gender and Race Discrimination in Retail Car Negotiations, 104 Harv. L. Rev. 817 (1991); Ian Ayres, Further Evidence of Discrimination in New Car Negotiations and Estimates of Its Cause, $94 \mathrm{MIrCr}$. L. Rev 109 (1995); Jeswald Salacuse, Ten Ways That Culture Affects Negotiating Style: Some 
likely to internalize blame and men to externalize it, while at the same time women are more likely to go to doctors and to bring legal claims. 48

While much of this very useful research on the distortions or errors of common human cognition is making its way into the negotiation literature ${ }^{49}$ and is one of the ways we can focus on problem solving and decision making in legal matters, it may have the effect of increasing negative rules and findings and may often overload and paralyze the potential negotiator or problem solver with negative prescriptions of what not to do. ${ }^{50}$

Survey Results, 14 NEG. J. 221 (1998); Stephen E. Weiss, Negotiating With Romans, Part 1, 35 Sloan Mgmt. Rev. 51 (1994); Stephen E. Weiss, Negotiating With Romans, Part 2, 35 Sloan Mgmt. Rev. 85 (1994).

48. See Sandra Lipsitz Bem, The Lenses of Gender: Transforming the Debate on Sexual Inequality (1993); Hazel Genn, Hard Bargaining: Out of Court Set. tLement in Personal Injury Actions (1987); Hazel Genn, Paths to Justice: What People Do and Think About Going to Law (1999); Carol Tavris, The Mismensure of Woman 36-43, 170-207 (1992); Herbert Kritzer et. al., The Aftermath of Injury: Cultural Factors in Compensation Seeking in Canada and the United States, 25 LAW \& Soc'Y Rev. 499 (1991); Herbert Kritzer, Propensity to Sue in England and the United States of America: Blaming and Claiming in Torts Cases, $18 \mathrm{~J}$. Law \& Soc'Y 400 (1991); Carrie Menkel-Meadow, Teaching About Gender and Negotiation: Sex, Truths and Videotape, 16 NEG. J. 357 (2000).

49. See Arrow et al., Barriers to Conflict Resolution, supra note 42; Russell Korobkin \& Chris Guthrie, Psychological Barriers to Litigation Settlement: An Experimental Approach, 93 MicH. L. REv. 107 (1994); Mnookin, Why Negotiations Fail, supra note 26.

50. The study of cognitive biases is a negative one. Researchers define errors as departures from rational thinking, see for example, JoN ELSTER, ALCHEMIES OF THE Mind; RATiONALITY AND the Emotions, (1999). With a different baseline we could study decision making descriptively in naturalistic settings (as Gary Klein and others have done) and perhaps discover that truly rational decision making is the deviance from the norm that should be explained, not the other way around. Kahneman \& Tversky's work, while path-breaking, has been criticized on this ground and others. See L. Jonathan Cohen, Can Human Irrationality be Experimentally Demonstrated? 4 Beh. \& Brain Sciences 317 (1981); L. Jonathan Cohen, Can Irrationality be Discussed Accurately, 7 BeH. \& Brain ScIENCES 736 (1984) (discussing difficulties of definitions of "irrationality" or departures from rationality, measurement problems, cueing problems in such research and philosophical objections to operationalization of irrationality heuristics); L. Jonathan Cohen, The Controversy About Irrationality, 6 BeH. \& Brain Sciences 510 (1983). Teresa Amabile has commented that most of her studies of creativity have uncovered the impediments to or suppressors of creativity, rather than finding empirically valid enhancers. See Amabile, supra note 8, at 243. For an argument that lawyers may have a particular need to hold on to assumptions of rationality, both in their own behavior and in the larger rationality of the legal system, see Langevoort, supra note 46, at 1526 (suggesting that the myth of the rationality of law allows us to maintain (perhaps incorrectly) the illusion of control over our world). Langevoort does note that a remarkable amount of productive work is 
Thus, this article explores the more positive models of problem solving-using descriptions of successful legal problem solving, creativity and multiple intelligences ${ }^{51}$ as a heuristic for teasing out the common elements of how we creatively (in our own domain) solve legal problems.

One can structure a problem solving approach to negotiation by focusing on a three step process in which first, the lawyer identifies multiple classes of needs, ${ }^{52}$ objectives, interests or goals from one's own client. Then, s/he proceeds to do the same for other parties involved, using information available from public knowledge, research, client knowledge and from the negotiation session. Finally, the negotiator examines and matches loci of complementary and then conflicting needs and interests of the parties, in a systematic way, in order to craft solutions that maximize joint gain or Pareto-optimal solutions. We can explore needs, interests and objectives in categories: (1) legal, the need for a ruling, judgment, legal status, or precedent; (2) economic, including transaction costs and present and future values; (3) social, including dealing with the parties' group or membership needs and objectives such as family, workplace, organizational, joint responsibility or community; (4) psychological, including all individually important needs or objectives including risk preferences,

accomplished by our legal institutions and questions whether the work on biased cognitive processes will prove to be as empirically robust at the organizational/institutional level as it is at the individual level.

51. In reviewing the now vast literature on both the psychology and sociology of cognition, one cannot help being struck by the different professional dispositions of researchers in the field. Some seem almost gleeful in rigorously documenting human error and intellectual frailty (as well as bell-curve variations) while others have attached themselves to the study of achievement (the rareness of true creativity) and the acknowledgment of greater human variations. Is this "glass half full or half empty" phenomenon parallel to the dispositions of traditional and problem solving negotiation theorists and practitioners?

52. My use of needs rather than interests alone has been quite deliberate and reflects several important jurisprudential challenges to conventional conceptions of negotiation in the legal system. First, lawyers should have an obligation to explore client's needs that may be beneath the articulated surface, both for individuals who may not be able to express those needs readily and for organizational or entity clients who may need to be reminded of long-term needs of the organization, rather than short-term goals of the person representing the entity. Second, my theory of problem solving negotiation is heavily influenced by work in feminist theory that suggests that clients have needs that may not be fully recognized by the formal legal system, see for example, ROBIN West, CARING FOR JUSTICE (1997); Robin West, The Difference in Women's Hedonic Lives: A Phenomenological Critique of Feminist Legal Theory, 3 Wis. WoMEN's. L. REv. 81 (1987), but which may be appealed to in negotiation settings. Third, expression of needs may compel an attention to justice in negotiation settings that is less instrumental than satisfaction of interests and more expansive than appeals to legal rights in the formal justice system. 
reputational, emotional, mental and physical health concerns, needs to assert, fear of shame, guilt, publicity; (5) political, such as rule change, justice, internal or public organizational concerns, precedent setting, relation to other problems, constituents, and finally, (6) moral, ethical or religious, including concerns about traditions, and fairness. Canvassing needs, objectives and goals in these and other categories, for both present and future desired states, ${ }^{53}$ is usually effective in bringing to the fore issues that may be of concern to a party in a negotiation context.

Like the pieces of puzzles and brainteasers (discussed infra), the creative problem solver lines up the needs and interests of the different parties and examines what solutions may be possible in reconciling and meeting all parties' needs and objectives. These solutions will eventually have to be tested against what is really possible within our domain-law. ${ }^{54}$

Often a solution to a negotiated problem may be illuminated by exploring the characteristics of the "problem" mapped over the parties' particular needs and interests. WHAT is the problem about? (What is the res? What is at stake? Can the thing itself be altered in any way?) WHO is involved? Are there stakeholders other than the parties formally at the table? Does adding parties facilitate a solution, or, as in the case of bringing in an insurer, does one increase those who can contribute to a solution, or, as in the case of the IRS, which is always a party to a legal negotiation, do tax concerns change the dynamics and suggest other solutions? WHERE is the transaction/ dispute/res located? Does jurisdiction matter for the problem? What about the location is alterable? (e.g. employment disputes with multiple offices or government agencies can offer transfer opportunities). WHEN does the dispute or transaction have to be resolved? This factor has led to the important and structural solutions of annuity payments in tort cases, installment payment contracts, contingency

53. See Menkel-Meadow, Toward Another View of Legal Negotiation, supra note 3 , at 803. Lawyers need to learn through interviewing and counseling how clients rate their preferences-not all will conform to Maslovian hierarchies of human need.

54. The question of whether law and legal remedies should set the parameters for a just or fair solution in legal negotiation is a much debated subject. While law certainly may set the outer limits of preventing unlawful outcomes, it may be that parties in private negotiations will choose solutions that are not unlawful, but which are also different than what the law provides for in a particular situation. See Robert Condlin, Bargaining in the Dark: The Normative Incoherence of Lawyer Dispute Bargaining Role, 51 MD. L. REv. 1 (1992); Carrie Menkel-Meadow, Whose Dispute is it Anyway? A Philosophical and Democratic Defense of Settlement (In Some Cases), supra note 30; Jacqueline Nolan-Haley, Court Mediation and the Search for Justice Through Law, 74 WASH. U. L.Q. 47 (1996). 
pricing and risk allocations, as well as continuing options, accelerated or graduated payments and duties and a whole host of substantive time-based solutions for trials, contingencies and terminableupon-conditions arrangements. How may the matter be negotiated? Must solutions be conventional payments of money? Are other more creative solutions possible? In-kind trades? Apologies? Percentage of gross or net, instead of fixed sums? Contingent agreements? Secured obligations? Guarantors? Third party reviews? Can dispute resolution procedures themselves be altered? These framing questions for legal solutions to negotiated problems are a way of increasing the resources available for solving problems and probing for non-obvious solutions. ${ }^{55}$ This structure often helps to provide legal or non-legal principles for allocating resources or goods or to justify particular divisions when claiming occurs. Using these very general questions often allows other expert systems ${ }^{56}$ or even lay common sense ${ }^{57}$ solutions to enter an otherwise legally dominated domain of possible solutions. More recent work on systematizing allocation schemes for the distributive part of negotiation problems can draw on these frameworks for assessing values and weights and priorities in numeric, as well as qualitative, allocative systems. 58

As robust or helpful as these frameworks are, negotiators still need deep and rich informational resources from which to draw to answer these questions. Thus, good problem solvers must always expand their knowledge bases, as well as the sources of insight and new combinations that spark innovative solutions. By systematically and self-consciously exploring the processes and dimensions of creative and richly contextual thinking processes, legal problem solvers can expand their substantive, as well as processual, repertoire.

\section{0.}

55. See Menkel-Meadow, Toward Another View of Negotiation, supra note 3, at

56. Fisher \& Ury suggest approaching negotiation problems through the frames of other realms of expertise. See Fisher \& Ury, supra note 31 at 64. See also DownLD Schon, The Reflective Practitioner: How Professionals Think IN Action (1983); Donald Schon \& Martin Rein, Frame Reflection: Toward the Resolution of In:TRACTABLE POLICY CoNTROVERSIES (1994).

57. See Gerald Lopez, Lay Lawyering, 32 UCLA L. Rev. 1 (1984). Indeed, clients should always be asked, "so how would you like to see this turn out?" Clients, of all kinds, will often be a rich source of possible, and even innovative, solutions.

58. See Steven J. Brams, Fair Drvision: From Cake-Cutting to Dispute ResaLUTION (1996) (providing theoretical and empirical research support for several allocative regimes to achieve fairness in negotiated situations); Brasts \& Tarzor, supra note 32 . 


\section{Creativity, Multiple Intelligences and Problem Solving}

This section describes how work in creativity, cognition and multiple intelligences might illuminate some of the processes that both individual problem solvers and legal negotiators use to craft solutions to legally defined problems. Rather than focusing on what might go wrong in our reasoning processes, let's examine what could go right.

How do we creatively link a problem (some state desired to be improved upon ${ }^{59}$ ) to a solution in the specific domain of the law? How are legal problems solved both analytically (substantively) and behaviorally (as in negotiation with others)? Ideally, we could create a phenomenology of legal problem solving-studying and describing those successful efforts at using the law or legal concepts to solve problems, make transactions or change certain end states.

Although much of the theory and social psychology of creativity has focused on grand creativity-those who are really inventive or who have radically altered our thinking in some artistic or scientific domain, much of what has been learned about creativity may be applicable to those smaller domains of everyday legal problems rather than more grand "Constitutional moments."60 Specifically, to the extent that some forms of creative activity are social, and not merely individual, ${ }^{61}$ and that certain conditions may be more or less likely to foster, encourage or exploit creativity, there may be things we can do

59. A common definition of a problem to be solved now appearing in the legal literature with some frequency can be found in ALLEN NEwELl \& HerberT Simon, Human Problem Solving 72 (1972): "A person is confronted with a problem when he wants something and does not know immediately what series of actions he can perform to get it." As I have indicated in supra note 7, even the nomenclature of problem is itself problematic in the legal domain because some legal issues are matters, transactions, or events that are not necessarily experienced as problematic to the individuals engaged in them. The law may be somewhat juridogenic in that it creates legal problems for those who would form entities, buy and sell property, products or services, create or terminate relationships or do any number of things without realizing that the law or the state is an inevitable party to their private negotiations.

60. Bruce Ackerman, We The People: Foundations (1991); Bruce Ackerman., We The People: Transformations, $4-5$ (1998). Indeed, deep phenomenological, as well as historical, study of such group events as Constitution making and amending, demonstrate the creativity and complexity of legal negotiations at their fullest and highest levels. For an application of some negotiation theory to Constitution making, see Jon Elster, Strategic Uses of Argument, in BARRIERS TO CoNFLICT RESOLUTION 236 (Kenneth J. Arrow et al. eds., 1995); see also Jack Rakove, The Great Compromise: Ideas, Interests and the Politics of Constitution Making, 44 WM \& MARY L. REv 424 (1987).

61. An interesting body of work has confirmed that certain personal characteristics are associated with high levels of individual creativity-independence or non-conformance and selfishness, birth order, persistence and hard work, focus on particular problems and depth in domain, intrinsic motivational pulls, an ability to live with 
in our thinking processes, working environments, social behavior and educational processes to facilitate more creative legal problem solving. Thus, I suggest below that expanding modes of what counts as legal thinking might actually improve the number and quality of solutions to legal problems.

Psychologists have defined creativity as "a process by which a symbolic domain in the culture is changed, "62 "any act, idea or product that changes an existing domain or that transforms an existing domain into a new one," 63 "how the new comes into being," "the quality of products or responses judged to be creative by appropriate observers and ... also be regarded as the process by which something so judged is produced," 65 and "that process which results in a novel work that is accepted as tenable or useful or satisfying by a group at some point in time." 66 What distinguishes more modern conceptualizations of creativity from older Popperian notions ${ }^{67}$ is the recognition that creativity, as a process, can be studied and that it is rooted to a contextually based social and historical process of implementation, acceptance and evaluation by relevant others. In the words of Howard Gardner:

People are creative when they can solve problems, create products or raise issues in a domain in way that is initially novel but is eventually accepted in one or more cultural settings. Similarly, a work is creative if it stands out at first in terms of its novelty but ultimately comes to be accepted within a domain. The acid test of creativity is simple: In the wake of a putatively creative work, has the domain subsequently been changed? ...

ambiguity and tension, playfulness, outsider family, high expectations and deep commitment. See, e.g., AMIABILE, supra note 8, at 203-42; BoDEN, supra note 8, at 8; CSIKZENTMIHALY, supra note 8, at 61-76. Such personal characteristics may also be found among leading legal creative figures-see biographies of Louis Brandeis, Oliver Wendell Holmes, Thurgood Marshall, and Benjamin Cardozo, to name some of the prominent judicial examples. See also MIr. Justice (Allison Dunham \& Philip B. Kurland eds., 1956) (collected essays about several prominent judges throughout history).

62. CsikszentMinaly, supra note 8 , at 8 .

63. Id. at 28.

64. John B. WATSON, BEHAVIORISM (1925).

65. AMLABILE, supra note 8, at 33.

66. Morris Stein, Creativity and Culture, in Explorations in Crestrvity (Ross L. Mooney \& Taher A. Razik, eds., 1967).

67. Some creativity scientists suggest that the field was born in reaction to Karl Popper's assertions that all truly creative activity is irrational or intuitive and therefore not amenable to study, despite (perhaps in reaction tol his own dissertation on the psychology of thinking See KarL Popper, The Logic of Scientific Discovery (1959), quoted in Gerd Gigerenzer, Where do New ideas Come From? in Duanssions of Creatrvity (Margaret A. Boden ed., 1996). 
Creativity includes the additional category of asking new questions [or creating new fields or domains]. ${ }^{68}$

Creativity, as defined by at least one scholar, ${ }^{69}$ includes several components: (1) relevant domain skills required for any performance of creativity in a particular domain, including factual knowledge, technical skills and special talents required by the domain; ${ }^{70}(2)$ creativity relevant skills, including cognitive skills, working styles or heuristics for exploration of new pathways within a domain and (3) task motivation that determine how an individual approaches a particular task (with intrinsic, self-directed motivation being more effective than extrinsically oriented motivations). ${ }^{71}$

Scholars of creativity distinguish between big " $\mathrm{C}$ " breakthrough creativity, such as Einstein's relativity theory, and more incremental creativity such as the patterns of social research and the development of legal doctrine. Some argue there is no big " $C$ " creativity in the law, precisely because Anglo-American law, at least, is based on adherence to precedent and incrementalism. ${ }^{72}$ On the other hand, overruling major doctrines, such as changes in liability rules (nonprivity) and recognition of new rights (privacy) may have the effects of big "C" creativity on those governed by law and rules. It is also possible to see law as having benefitted from the communal big " $\mathrm{C}$ " creativity that produced the Constitution-a template for stability and elasticity ${ }^{73}$ that has been replicated in different forms throughout the world.

It is important for students of creativity to recognize that creativity occurs within a domain (a culture that contains symbolic rules) and, though created by an individual who produces the novel idea or product, is eventually judged by a field of experts who can understand, judge, test and implement the creative product. Some domains have larger fields than others-for example, in cultural

68. Howard Gardner, Intelligence Reframed: Multiple Intelligences for THE 21st CENTURY 116-19 (1999).

69. AMABILE, supra note 8 , at 83-127.

70. Interestingly, almost all psychologists studying creativity conclude that it takes at least ten years to become domain proficient (sufficient domain substantive knowledge) to be creative. See, e.g., CsikZENTIMIHALYI, supra note 8; GARDNER, INTEL LIGENCE REFRAMED, supra note 68; AMABILE, supra note 8.

71. Some studies which attempt to measure quality of creative contributions to a field suggest that commissioned works are never as good as internally driven ones. So, why do we legal scholars appear at commissioned symposia?

72. Edward H. Levi, An Introduction to Legal Reasoning (1949); Karl N. Llwellyn, Bramble Bush (1930).

73. See Robert Paul Weiner, Creativity \& Beyond: Culture, Values and Change 128 (2000). 
production, movies, novels and art will be evaluated not only by specialized critics but by purchasers and the consuming public at large. And, in some domains, the judgments about creative worth may be subject to more volatile change than others, for example, the debates about canons in literature, art and the "classics."74 The law represents a hybrid domain in which the field is that of fellow experts (judges, legal scholars, lawyers) but in fact the lasting creativity of legal work will be measured by a much broader field-that of clients, citizens of legal regimes and all those regulated by law. ${ }^{75}$ There are also more creative times than others, when "critical masses" of creative people are presented with problems to solve or resource-rich communities in which to explore their interests-the Athenian "Golden Age," the Renaissance, late 19th century Paris (Impressionism), Fin de Siecle Vienna, Motown, and the " $M$ \& $A^{n}$ decade. ${ }^{76}$

Students of creativity and cultural evolution speak of memes as units of analysis. Memes ${ }^{77}$ are the cultural equivalent of genesunits of information that are passed on to future generations and that can be changed. Like successful mutations, if a changed meme is accepted by enough people in the culture, the culture will change. While we currently think of Brown v. Board of Education ${ }^{78}$ as a successful meme of the legal culture (in the now accepted idea it expressed about racial equality; it has been less successful as a meme of implementation of educational equality), other legal memes are still trying to gain acceptance (Roe $v$. Wade ${ }^{79}$ ), and still others are trying to seek recognition and acceptance by the legal field (e.g., same sex marriage ${ }^{80}$ ). While I will more fully explore legal creativity and legal memes in Part IV below, consider that joint custody for children after divorce is a legal meme that was produced by the negotiation process,

74. See, e.g., Allan Bloom, The Closing of the American Mind, in Debating PC: The Controversy Over Polrtical Correctness on Campuses (Paul Berman ed., 1992); Robert Hughes, Culture of Complaint: The Fraytng of America (1993); Martha Nussbaum, Cultivating Humanity (1997).

75. For an illustration of how average citizens creatively mobilize their complex and sometimes conflicting understandings of law see PatrucL EwICK \& SUSAN Silbey, The Conmon Place of Law: Stories From Everyday Life (1998).

76. See lincoln Caplan, Skadden: The Rise of a Legal. Empire (1993).

77. Susan Blackmore, The Mene Machine (1999); Csikszentuhhuly, supta note 8 , at 7 .

78. 347 U.S. 483 (1954).

79. 410 U.S. 113 (1973).

80. See Baehr v. Miike, 1996 WL 694235 (Haw. Cir. Ct. Dec. 13, 1996); see also 2000 VT. Acts \& Resolves 91 and VT. Stat. ANN. tit. 15, $\$ 3$ (2000) (allowing same sex couples the right to have "civil unions" in Vermont). 
when creative lawyers (or perhaps clients) decided to change the pattern of separate physical custody of one parent after divorce and instead use a common negotiation trope of sharing to produce a new legal result, now codified (and some would say, calcified ${ }^{81}$ ) in formal legal presumptions, ${ }^{82}$ at least in some states.

What makes the study of creativity interesting for legal negotiators and problem solvers is the extent to which debates about whether creativity depends on internal or external rewards, ${ }^{83}$ motivations or constraints may inform how we study and teach our own thinking processes. Modern students of creativity see it as both an interpersonal and social process, so that mastery of the knowledge of the domain is necessary (but not sufficient) by the individual, but some degree of acceptability by the relevant group of experts will ultimately be necessary. Some fields may be more social than others, affecting how domain knowledge is transferred as well as evaluated. Consider the transparency of law in which legal arguments are made publicly and evaluated in writing by lawyers and judges or how transactional clauses are accepted or rejected by lawyers and clients. Unlike scientists working in secret labs $^{84}$ until they are ready to share their findings for peer review, lawyers and legal scholars must share their ideas rather quickly, if not in print, then in negotiated proposals, offers, paper presentations, motions, briefs and arguments.

Domains may have both specific knowledge bases and domainspecific processes. Consider the formal art training that Picasso and many of the Impressionists had before they broke with conventional forms. In law, we teach the specialized learning process of thinking like a lawyer ${ }^{85}$ by which we mean teaching particular cognitive processes, including the ability to choose what is relevant, the ability

81. See, e.g., Katharine Bartlett \& Carol Stack, Joint Custody, Feminism and the Dependency Dilemma, 2 Berkeley Women's L.J. 9 (1986); Carol Bruch \& Janet Bowermaster, The Relocation of Children and Custodial Parents: Public Policy, Past and Present, 30 FAM. L.Q. 245 (1996).

82. Cal. Fam Code $\S 3002$ (West 2000).

83. Teresa Amabile's research, for example, suggests that creativity is enhanced by internal motivations and often destroyed by many, if not all forms of externals rewards, expectations and constraints. See AMABILE, supra note 8, at 243.

84. For more on the "secret" lab competition in DNA research, see ANNE SAYRE, Rosalind Franklin and DNA (1978); James D. Watson, The Double Helix: A Personal Account of the Discovery of the Structure of DNA (1969).

85. For several of the classic efforts to define what this means, or at least consists of, see Edward H. Levi, AN INTroduction to Legal REASONING (1949); KARL Llewellyn, The Bramble Bush: ON OUR Law and Its Study (1930). For a contrary view that we should be learning other cognitive skills, such as more fact-based analysis, see Jerome Frank, Courts on Trial: MYTH aND REality in american JUSTICE (1949). 
to think deductively as well as inductively, and the ability to reason analogically. Creativity is most often exercised within a specific domain of substantive knowledge (e.g., "the law" or "common legal practices") and is expected to be developed within the method (e.g., common law reasoning, the scientific method) that is appropriate for the domain. Some domain-changing creativity challenges domainspecific methods, as well as knowledge of the field. Thus, teaching law students to create and synthesize (a deal, a document, a legal strategy) is different than focusing the whole of legal education on analysis and logical deduction. ${ }^{86}$

Distinct from efforts to account for and explain the conditions of individual creativity, Howard Gardner's multiple intelligences theory $^{87}$ suggests there are multiple intelligences or potential competencies at the individual level, not only at the field or domain level. Thus, rather than one general intelligence (as measured by logical numerical and verbal tests and values ${ }^{88}$ ) each human being has several different faculties and potential competencies. Different problems are best addressed by different intelligences. ${ }^{89}$ Gardner makes two essential claims about intelligence: (1) that a full description of human intelligence must take account of multiple (now $81 / 2$ ) intelligences that go beyond Socrates' rational man or Freud's irrational animal, each of which may be mobilized both by individual inclinations and cultural preferences or societal needs, and (2) that each individual has unique measures or expressions of these intelligences that may be educated for and mobilized in different ways. Creative products in particular cultural domains may be produced by marshaling the intelligences associated with a particular domain, although Gardner cautions us not to conflate complete correspondences between domains and particular intelligences, or by combining some variants of the multiple intelligences.

For lawyers, who clearly must have some linguistic intelligence within Gardner's frames of reference, it is interesting to imagine how increased attention to other intelligences, both in the educational

86. There are an increasing number of arguments that thinking like a lawyer will no longer be logically linear when we incorporate the logic of computer use and completely different forms of less linear thinking, see, for example, Barbara Bintliff, From Creativity to Computerese: Thinking Like A Lawyer in the Computer Age, $88 \mathrm{LAw}$. LIBR. J. 338 (1996); Diana R. Donahoe, at www.teachinglaw.freewebsites.com (last visited February 18, 2001).

87. See Gardner, Framies of Mind, supra note 10.

88. See Robert J. Sternberg, The Holey Grail of General Intelligence, 289 Sciesice 399 (2000).

89. Gardner, Intelligence Reframed, supra note 68 , at 33. 
process (see Part V infra) and in the practice of legal problem solving might facilitate the enhancement of certain problem solving capacities, if not creativity, in the legal domain. Combining this work on creativity and multiple intelligences for lawyers presents some interesting possibilities for encouraging more positive ways of thinking about legal reasoning and problem solving, if learning from different intelligences can be made relevant within one domain (legal problems).

Gardner originally posited seven intelligences, as follows:

1) linguistic-word and language related;

2) logical-mathematical-use of logic, mathematical operations and scientific investigation;

3) musical-performance, composition and appreciation of musical patterns;

4) bodily-kinesthetic-use of body to solve problems (athletes, dancers, surgeons, craftspeople);

5) spatial-recognition and manipulation of patterns of wide or confined spaces;

6) interpersonal-capacity to understand the intentions, motivations and desires of other people, and ability to work well with other people;

7) intrapersonal-capacity to understand oneself;

More recently, Gardner has added several new intelligences: ${ }^{90}$

8) naturalist-expertise in the recognition and classification of numerous species of the environment;

9) spiritual-relation to supernatural world or larger cosmos; ability to achieve other states of consciousness;

10) existential-concern with ultimate issues and a capacity to locate oneself with respect to the furthest reaches of the cosmos and existence-ability to imagine and contemplate the infinite: the cognitive side of spiritual intelligence. ${ }^{91}$

While some have urged the addition of a moral intelligence, Gardner declines to recognize that as a separate intelligence and instead suggests that each intelligence can be expressed with positive

90. Id. at 35-41. Gardner specifies the bio-neurological and psychological factors that set the parameters for recognition of an "intelligence" with both biological and empirical components. Not all intelligences are clearly mapped in the brain.

91. Id. at 47-66. Because the last two, spiritual and existential intelligences have not been as fully established by Gardner's own standards, he now speaks of " $81 / 2$ " intelligences. Howard Gardner, Kenote Address at the Hewlett Center Conference 2000: Focus on Negotation Pedagogy (Mar. 10, 2000). At least one dispute resolution scholar has been exploring the relationship of spiritual intelligence (in the form of meditation) to lawyering. See Len Riskin, Project on Meditation and Lawyers, Yale Meditation Project. 
and negative values. He maintains that our choices about how to exercise our intelligence is a question of values and judgment, not intelligence. ${ }^{92}$ Those psychologists and others who study altruistic behavior might disagree; some empirical and socially defined characteristics of rescuers, for example, illustrate some patterns of intelligence, such as capacity for empathy and pro-active moral actions. ${ }^{93}$

Gardner himself has speculated on the intelligences that might be marshaled for effective negotiation and legal problem solving: linguistic, logical, interpersonal, intrapersonal, and even spatial, are obvious candidates. ${ }^{94}$ Consider how we narrow the domain of legal problem solving by focusing so much of our education and knowledge base on only one or two of these intelligences.

Much of the popular literature on learning how to be creative ${ }^{95}$ uses the approach of making people aware of more ways to think about particular problems -in essence to access their multiple intelligences, to avoid narrow domain-limited and path-dependent ${ }^{96}$ ways of both framing and solving problems and to "think out of the box." Brainteasers and other brain exercises are used to question assumptions, unpack stereotypic thinking, juxtapose elements of a problem, make "the familiar strange,"97 change levels of thinking (aggregation and disaggregation of problem elements), develop new frames, analogies or metaphors, and to avoid pre-judging or prematurely settling on particular solutions. Some brainteasers and problems designed to

92. Gardner, Intelligence Refranied, supra note 68, at 67-77.

93. See Carrie Menkel-Meadow, Is Altruism Possible in Lauyering?, 8 Geoncin St. L. Rev. 385 (1992); see also Samuel P. Oliner \& Pearl M. Oliner, The Altruutstic Personality: Rescuers of Jews in Nazi Europe (1988); Mintt Ridley, The Ora. gins of Virtue (1997); Elliott Sober \& David Sloan Wilson, Unto Others: The Evolution and Psychology OF UNSElfish Behavior (1998).

94. Gardner, Intelligence Refranied, supra note 68, at 47-66; Howard Gardner, Using Multiple Intelligences to Improve Negotiation Theory and Practice, 16 NEG. J. 321 (2000).

95. I will simply assume here that we are talking about small "c" creativityenhancements to producing novel or useful products within a domain (like law)-new or effective legal ideas, concepts, doctrines, clauses, structures or arrangements.

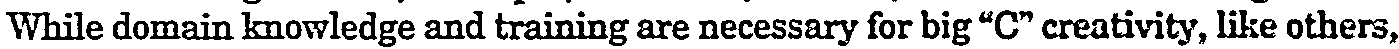
I believe it is unlikely we can teach someone to be creative in that big, breakthrough way, although problem presentation in an educational environment may sparls motivation or inspiration.

96. Oona A. Hathaway, The Path Dependence of the Law: The Course and Pattern of Legal Change in a Common Law System, at http://www.bu.edu/law/faculty/papers/ (last visited February 18, 2001).

97. A creative process, making use of analogical thinking, called "synectics," see Whliam J.J. Gordon, Synectics: The Developaent of Creative Capacity (1961). 
enhance creativity also teach about the process of thinking, which includes listening, exploring multiple meanings of language and focusing on less familiar modes of thoughts. A few of these exercises follow below. As you attempt to solve these problems, pay attention to your own thinking processes-how are you trying to solve the problem? What problem or domain space ${ }^{98}$ are you searching? What do you call on, from what you already know, to try to solve these problems?

1. In what has become the canonical problem for literally, and figuratively, demonstrating this point, consider the following: Connect the three rows of dots below with four straight lines without moving your pen off the page:

Now, try connecting the dots with three lines.

Now, try one. ${ }^{99}$

The solution to the first problem involves "thinking out of the box" and by realizing that most people imagine a closed box or frame within which they think the lines must be drawn. Those with both spatial and some forms of linguistic intelligence may solve this problem more quickly than others by not feeling so constrained by what they hear as the instructions. The next two problems involve some manipulation of the media or problem materials. The dots must be made a bit larger to use three lines and we must stretch our sense of "line" to imagine one large line to cover all the dots. Or, we must change the paper on which the lines are drawn in order to line them up one by one. ${ }^{100}$ Law students, and even some law professors, resist

98. Scholars of decision making and problem solving describe the process of problem solving by mapping out a problem space that creates the terrain for cognitive searching, see, for example, Newell \& Simon, supra note 59, at 59. This can also be considered framing the problem and this first step is quite crucial to how we go about solving the problem. Recent work on problem solving from several different domains suggests that many people do not use the rational search for alternatives posited by rational choice theory, but especially among skilled experts, the "search space" is generated from past experiences and quick single decisions are made with a trial and error evaluation process, called "recognition-primed decision making," see KLEIN, supra note 10, at 7 (describing firefighters' decisions about how to attack fires, without information about cause or specific locations).

99. For solutions, see James A. Adams, Conceptual Blockbusting 24-32 (3rd ed. 1986).

100. Id. at 26-31. 
the manipulation of words or material that is required by this problem. Is this teaching people to manipulate rules, instructions and to transgress the "box" of laws that comprise our legal system?

2. Now, take a piece of paper and put your body through the page. ${ }^{101}$ The solution to this problem requires some alteration of the media in which you are working. Word manipulation? Creative use of spatial intelligence?

3. You have four cows in a field. How can you arrange those cows so they are equidistant from each other? (Hint, this too calls on spatial intelligence and manipulation of media).

4. A taxi-driver becomes annoyed with a particularly loquacious passenger. He realizes he has not said a word during the whole trip so he signals to his ears to indicate he is deaf. The passenger quiets down. Later, after the passenger has left the cab, she realizes a trick has been played on her. How does she know? ${ }^{102}$

5. A surgeon is asked to rush to the operating room after a car accident. The surgeon is told a father and his son have been brought in, but the father has died and the son needs emergency surgery. Upon entering the Operating Room the surgeon gasps, "Oh my God, that's my son!" How can this be?103

6. You are in a hotel going to a cocktail party during a conference and have no pockets or handbag. Where can you put your key so both your hands are free to hold drinks and hors d'oeuvres? (There are many solutions to this problem.)

These examples illustrate just a few points about creative problem solving in negotiation. Framing, creating and implementing solutions can be done in many ways, so focus on precedents, standard clauses, conventional solutions and a limited defined problem space can actually hinder what we think is possible in solving legal

101. I will not put the solution in print, but will tell you the answer if you contact me, meadow@law.georgetown.edu, because I do not want my future students to be able to research the answer.

102. GARDNER, AHA! INSIGHT, supra note 13. You will find this brain teaser, along with many others used in negotiation classes to teach students to listen carefully and pay attention to detail, in Martin Gardner's two books of brainteasers and puzzles which are designed to teach, through problem solving, a number of intelligences, including mathematical, quantitative, logical, linguistic, social (breaking of stereotypes) and spatial. See also, Gardner, aha! Gotcha: Paradones to Puzzle nNd Delight, supra note 13.

103. Martin Gardner has a series of brainteasers like this one, see GARDNER, AHA! INSIGHT, supra note 13, at 95, that are designed to explore the stereotypes we employ when we visualize a scene from the spoken word and make unnecessary and limiting assumptions about what the scene is about. 
problems. By using puzzles and brainteasers of various kinds, students and negotiators are forced to confront their own processes of cognition or problem solving and expand the realms of possible information and solutions they seek. After being stuck in an impasse in a negotiation, students who stop and do a few brainteasers will often re-approach a problem with new ideas, insights, and often, different ways of looking at the problem.

In teaching legal problem solving, some choose to highlight the rational choice, decision making model (evaluation of already generated alternatives), ${ }^{104}$ while others seek to systematize the teaching of creativity. Popular writers like Edward de Bono ${ }^{105}$ and Gerard Nierenberg ${ }^{106}$ seek to develop models, with specific techniques and exercises in order to broaden the search frames that most people use in both everyday problems and more complex expert based problems. ${ }^{107}$ For instance, Edward de Bono asks us to consider what is good, bad or interesting about something, suggesting that we counter and delay judgments with curiosity and possibility or "po"108 ( the provocative rearrangement of information) as we restructure or reposition the possibilities. In this literature, the following techniques are suggested as formal ways of enhancing creativity, solving problems and suggesting new ideas, some as separate individual cognitive processes, and others as structured processes to be used in multiparty settings:

1. Use of analogy (direct, fanciful) and use of metaphor;

2. Aggregation/disaggregation/re-combination of elements of a problem;

3. Transfer (cross-disciplinary use of concepts, ideas, information, solutions from other fields);

4. Reversal (either extreme polarization or gradual modification of ideas)-which is done both in cognitive and in personal forms (as in role-reversal efforts to understand the point of view of others in the situation);

104. See, e.g., Paul Brest \& Linda Krieger, Lawyers as Problem Solvers, 72 TEMP L. REv. 811 (1999).

105. DE BONO, supra note 13.

106. NiERENBERG, supra note 13.

107. See also HuRT, surpa note 13; Donald J. Noone, supra note 13; RoBer'T W. Olson, supra note 13; VINCENT RYAN RUgGiero, supra note 13. For applications of creativity and problem solving to organizational change and management see, for example, Richard S. Blackburn, Managing Creativity in Academics, in Managina in ACAdemics (Jill Ridky \& George Sheldon eds., 1993); Jennifer JAMEs, THinking in THE Future TEnSE: A Workout For the Mind (1997).

108. De Bono, supra note 13, at 228-30. 
5. Extension-extending a line of reasoning, principle or solution beyond its original purpose;

6. Challenging assumptions-re-examining givens or problem statements and unpacking cliched, conventional solutions or stereotypes;

7. Narrative-fully describing facts and problems to elaborate on complexity, and producing alternative endings;

8. Backward/forward thinking-focusing on how we came to a particular situation (reasons why, causes) in order to figure out how we get to desired end-state(s);

9. Design-plan for desired future end-state, structures, means;

10. Random stimulation/brainstorming ${ }^{109}$ _separation of idea generation, randomly generated, from judgment and evaluation. As the field of group facilitation has developed, there are newer, more structured variations on these themes, such as Nominal Group Technique ${ }^{110}$ (a process of generating and then voting on solutions);

11. Visualization-use of different competencies and modes of thinking and processing information; this includes efforts at altered states (e.g., retreats and meditations);

12. Entry points-explicit reframing of problems and solutions from different perspectives, or in Gardner's terms, different intelligences.

Some of these techniques or descriptions of thinking are implicit in much legal reasoning and problem solving (analogy, backward thinking, forward thinking and design), but some of them are quite

109. The process of non-judgmental brainstorming in group settings was originally described by Alex Osborn, Applied Imagination: Principles and Procedures of Creative Problem-Solving (1963). It has continued to be validated as effective in practice-the generation of a large quantity of ideas tends to improve their quality, see AMIABILE, supra note 8, at 244-45.

110. See Hurt, supra note 13, at 56; Roger M. Schwarz, The ShIlled Facilitator: Practical Wisdom for Developing Effective Groups (1994). IDEO, a California-based company that creates products and services, utilizes a team method that includes voting on ideas generated from group brainstorming sessions. This process has been used successfully in the invention of such products as Crest's "Neat Squeeze" toothpaste dispenser and 3 Com's Palm Pilot V design. See http:ll www.ideo.com/ideo.htm (last visited February 18, 2001). This model has been adopted and adapted by other companies, is studied extensively in business school classes that teach team building, and written about by journalists and others. See Ed Brown, A Day at Innovation U: Can You Teach Creativity, at http:www.fortune.com/ fortune/careers/1999/04/12/sta.html (last visited February 18, 2001). See also To:s Kelley \& Jonathan LitTian, The Art of InNovation: Lessons in Creatrvity from IDEO, AMERICA's LEADING Design FirM (2001). 
outside the usual scope of legal problem solving. So, how can all of this creativity and multiple intelligences work be harnessed to legal problem solving?

\section{Legal Creativity and Problem Solving}

Is it possible to speak of legal creativity or is the phrase itself an oxymoron? Law is based on precedent, rule of law and gradual evolution of legal principles. Even this conservative discipline, however, has had its revolutionary moments. Consider three different forms of legal creativity that bear on legal problem solving. First, at the highest level of abstraction, we might consider what creative ideas that law as a discipline, or legal institutions, have contributed to the solving of basic human problems at the societal or system level. Second, how do legal memes or tropes of lawmaking come into being (e.g. common law and Constitutional doctrinal development) so they influence legal behavior, such as in problem solving in litigation and dispute contexts, as well as everyday compliance, mobilization or resistance to the law? ${ }^{111}$ Third, how are legal concepts created and used in the transactional context to develop legal entities, to manage arrangements in large institutions like corporations, as well as one shot buysell agreements and to enable and monitor daily human interactions? If we can understand the basic structure and sources of whatever legal creativity we have, we can better transmit a more systematic approach to developing solutions to legal problems to enhance the legal creativity of our students.

This section illustrates examples of legal creativity, drawing on the three categories of legal creativity (uniquely innovative legal ideas and concepts, processes of acceptance of legally creative ideas and the use, development and refinement of legal institutions, entities, transactions and clauses) by demonstrating how such legally creative ideas came to be. The examples here, though by no means

111. For a law and society scholar this represents a view of law from the outside: how do particular legal ideas, or ideologies, come into being and how are they used, mobilized or resisted by those affected by legal doctrines and rules? See Alan Hunt, The Ideology of Law: Advances and Problems in Recent Applications of the Concept of Ideology to the Analysis of Law, 19 LAw \& Soc'y REv. 11 (1985). Thus, a broader and more social view of legal creativity includes not just those who formally make the law (judges, lawyers, government officials) but those who implement it, are regulated by it and who translate it into everyday understandings. See e.g., EwICK \& SilBEY, supra note 75; Sally Merry, Getting Justice and Getting Even: Legal Consciousness Among Working Class Americans (1990); Regina Austin, Employer Abuse, Worker Resistance and the Tort of Intentional Infliction of Emotional Distress, 41 STAN. L. REV. 1 (1988). 
exhaustive, demonstrate that many of the creative processes described by creativity scholars and practitioners in other disciplines have, in fact, been used in law to create new concepts or ideas by interpreting or characterizing words, the constituent element of all law (by creatively reading and "misreading" prior concepts or tropes), expanding, aggregating, disaggregating, rearranging and altering existing ideas and concepts, borrowing or translating ideas from one area of law to another or from other disciplines, and finally, by use of re-design or architecture of words and concepts to build both new legal theories at the abstract level and new institutions at the practical level. In the paragraphs that follow we examine illustrations of these creative processes in legal problem solving. Some are the product of internal and individual negotiation (ideas developed by particularly creative individuals like Joseph Sax, Charles Reich and Catherine Mackinnon). Most legal ideas and solutions to problems, however, are the result of multi-party negotiations, such as our founding Constitutional Convention, ${ }^{112}$ or incremental cognitive negotiations with concepts and ideas that are changed by intelligent, and some would say "value creating"113 lawyers, in both disputing and transactional contexts.

Law as a discipline has contributed to the solution of human problems with the creation of institutions designed to preserve order and reduce or eliminate violence through the development of both governing principles and processes. Whether particular regimes or institutions are legitimate within a particular society, law and the institutions it creates are the glue which holds the society together by resolving disputes at both system-wide and individual levels. Law can be used illegitimately, as the Nazi and other fascist regimes demonstrated, but more commonly, law appeals to legal principles or processes are legitimately used to get things done. ${ }^{114}$ To the extent that we continue to view our own Constitution as the ultimate creative act, ${ }^{115}$ in its creation of a structure of government with checks and balances, separation of powers and federalism that places great

112. See John Elster, Strategic Uses of Argument, in BArRuErs to Confuct REsa. LUTION (Kenneth J. Arrow et al. eds., 1995); Jack Rakove, Original Menniscs (1996); Dana Lansky, Proceeding to a Constitution: A Multi-Party Negotiation Analysis of the Constitutional Convention of 1787, 5 HARv. NEGot. L. REv.279 (2000).

113. MNOOKIN ET AL., Beyond Winning, supra note 26.

114. Robert Cover, Violence and the Word, 95 Yale L.J. 1601 (1986).

115. Regarded by many as deeply flawed from its inception because of its recognition of many inequalities (including slavery). This raises the question of the temporality of measures and assessments of creativity. 
emphasis on the process of governance, it is not surprising that negotiation theorists want to claim for lawyers the moniker of process architects. ${ }^{116}$ Our Constitution and much American law has also created substantive legal concepts and ideas, which in turn influence the legal behavior of those regulated or acted upon. Where do the ideas for these substantive legal concepts come from and how do new ones arise and become recognized? Virtually all of our legal ideas have been negotiated, whether in the august chambers of constitutional conventions or the more common locations of law offices and conference rooms.

Except for those rare revolutionary moments, when legal ideas are plentiful and debated by many, we tend to think of the development of legal concepts and principles as gradual, incremental and not necessarily creative. A limited number of cognitive processes are thought to govern the development of new legal ideas, ${ }^{117}$ such as reasoning by analogy, or its converse, differentiation, ${ }^{118}$ and the use of inductive logic, as well as deductive logic. Some would argue that as one of the most creative breaks in legal intellectual history, law and economics has added some further cognitive processes to the mix. We

116. Ronald Gilson \& Robert Mnookin, Foreword: Business Lawyers and Value Creation for Clients, 74 OR. L. REv. 1, 8-9 (1995); MNookIn ET AL., BEYond WinNina, supra note 26. And in an interesting reversal, social theorists and historians have recently been applying negotiation theory to constitution formation. See Elster, supra note 60 and Rakove, supra note 60 , for examples of the exploration of the differences in bargaining procedures utilized in different constitutional settings.

117. Despite the recent increase in attention paid to legislation, as Eskridge \& Frickey have done, and regulation, most classic studies of legal processes still focus on judicial common law development. See Benjamin Cardozo, The Nature of the Judi. cial Process (1921); Oliver Wendell Holmes, The Path of the Law (1897); Llew. ellyn, supra note 85; cf. Henry M. Hart, Jr. \& Albert M. Sacks, The Lecal, Process: Basic Problems in the Making and Application of Law (William N. Eskridge, Jr. \& Philip Frickey eds., 1994). For more nuanced and recent case studies on how laws are made, see Case Studies in Consensus Building Handbook (Larry Susskind et al. eds., 1999); Wendy Espelund, The Struggle for Water: Politics, Rationality and IDENTITy IN THE AMERICAN Southwest (1998); Jody Freeman, Col. laborative Governance in the Administrative State, 45 UCLA L. REv. 1 (1997).

118. Law students are taught analogical reasoning and the "distinguishing" of cases, to be able to argue for both inclusion or exclusion of particular facts from arguably applicable rules. Interestingly, in recent empirical work on effective modes of teaching negotiation, Leigh Thompson and her colleagues, of the Northwestern Kellogg School of Business, have demonstrated that explicit comparison of cases, drawing analogies in the characteristics of cases may increase the likelihood of pattern recognition and produce "better" outcomes (in that case, conceptualized as more flexible, contingent clauses). See Jeffrey Loewenstein et al., Analogical Encoding Facilitates Knowledge Transfer in Negotiation, 6 Psychonomic Bull. \& Rev. 586 (1999); Leigh Thompson, et al., Avoiding Missed Opportunities in Managerial Life (2000) (manuscript). Perhaps legal educators are doing something right, after all. 
utilize rational choice theory, wealth maximization and efficiency concerns to affect that more ambiguous form of legal reasoning-policy analysis-in making choices among possible rules or creation of new ones. More recently, some use of statistical and empirical ideas (such as logical-mathematical intelligences) have found their way into legal reasoning (e.g. antitrust, employment discrimination) and even the economists have begun to take note of the psychological forces affecting rational man. ${ }^{119}$ I have argued elsewhere ${ }^{120}$ that it is interesting to note the differential take-up rates of different modes of thought or disciplines (intelligences?) in legal reasoning. As we begin to explore the broadening of disciplines, domains or intelligences that might contribute to legal reasoning, there will be difficult questions of transferability, evaluation and verification, ${ }^{121}$ but an opening out is necessary to spark legal creativity and to encourage a broader range of both solution generation and methods of solution evaluation.

Lawyers work with words, so most of our creative acts involve the construction of new language and interpretation of existing language, creating new concepts from whole cloth or from the interstices of statutory, regulatory or contractual gaps. Our words have the force of law behind them, however, so that powerfully creative words in law have been known to create whole new institutions. Examples of new legal and real entities that have been created are corporations,

119. For a summary of the new use of behavioral, social and cognitive psychology in law and economics and legal scholarship more generally see Langevoort, supra note 46; see also Russell B. Korobkin \& Thomas S. Ulen, Law and Behavioral Science: Removing the Rationality Assumption from Law and Economics, 88 CAL. L. REv. 1051 (2000).

120. For comparisons of law and the social sciences other than economics, see Carrie Menkel-Meadow, Durkheimian Epiphanies: The Importance of Engaged Social Science in Legal Studies, 18 FLA. ST. U. L. REv. 91 (1990). For a comparison of legal feminism with law and economics, see Carrie Menkel-Meadow, Mainstreaming Feminist Legal Theory, 23 PAc. L.J. 1493 (1992). Others have focused on the use of literary criticism and humanistic studies, see, for example, Martha C. Nussbnum, Poetic Justice: The Literary Imagination and Public Life (1995); Robin West, Narra. TIVE, Authority AND Law (1993); James Boyd White, What Can A Lauyer Learn from Literature?, 102 Harv. L. Rev. 2014 (1989); of. Richard Posner, LaW and LiteraTURE: A Misunderstood Relation (rev. ed. 1998).

121. It is sometimes suggested that law and science and law and social science operate with such different standards of proof that they are hard to reconcile, especially in courts of law. See, e.g., Steven Goldberg, Culture Clash: Law and ScIence in Adierica (1994); Shemla Jasanoff, Science at the Bar: Law, Science and Technology in America (1995). In some cases, law is more demanding than science (epidemiological proof in mass torts), requiring degrees of certainty not yet known to science. In other cases, courts have tolerated what others call junk science if there is at least one expert to testify to some scientific truth. Sce Daubert v. Merrell Dow Pharmaceuticals, Inc., 509 U.S. 579 (1993). 
trusts, regulatory agencies, condominiums, unions and tax shelters. In addition, our words have created new legal rights and constructs like leases, sexual harassment, probation-and also have recognized (sometimes from conflicting ideologies) new claims like civil rights, privacy, free speech and emotional distress.

Words have also been creatively interpreted or "misread" by lawyers or judges, seeking to alter, expand, contract or even radically change a legal concept or doctrine. David Cole, for example, has suggested that "creative misreadings" by several notable justices of First Amendment doctrine creatively fashioned our First Amendment jurisprudence. ${ }^{122}$ Cole applies the literary analysis of Harold Bloom's The Anxiety of Influence (1973), to suggest that judges, like poets, are caught between emulation of tradition and creative breaks with the past. ${ }^{123}$ Dissents, in particular, offer an opportunity for oppositional ideas to be expressed and gradually to become less shocking and more acceptable. ${ }^{124}$ Cole traces the development of First Amendment law through Justice Holmes, Brandeis, Black and Brennan's "creative misreadings" of precedent to develop such legal memes as "clear and present danger," "free trade in ideas" which became the "marketplace of ideas," and the resultant change in legal doctrine from one restricting speech to one increasingly tolerant of even subversive speech. ${ }^{125}$ As Cole artfully argues, Justice Holmes, by dissenting from himself, used the common forms of legal reasoning by employing background philosophical principles derived from Blackstone, Smith and Mill, expressed in pithy metaphors which are themselves altered by context and by interpretations of subsequent readers (other judges). ${ }^{126}$ Constitutional adjudication has been particularly subject to this form of creative literary process as words and metaphors are used to break from the past and legal memes are needed to build legitimacy and acceptance for breaks from the past. As Brown v. Board of Education ${ }^{127}$ ushered in an era of "separate is not equal," the requirement to integrate "with all deliberate speed" was an effort to use the lawyer's tools of words to effectuate a more gradual compliance with a revolutionary and creative newly announced principle. Note that the choices of language or metaphors can be problematic as well.

122. David Cole, Agon at Agora: Creative Misreadings in the First Amendment Tradition, 95 YALE L.J. 857 (1986).

123. See Id. at 858 .

124. See Id. at $860,869-71$.

125. Cole, supra note 122 , at $875-96$.

126. Id. at 879-87.

127. 347 U.S. 483 (1954). 
As Justice Blackmun chose "viability" of the fetus as a way of finessing religion by using science in Roe $v$. Wade, ${ }^{128}$ a new justifying principle is needed as science moves viability ever forward. Thus, a judge's and lawyer's creativity may be measured by the "viability" of the legal meme or trope that he creates.

At the opposite end of "creative misreadings" is the cognitive process of extension. One of the major legally creative acts in modern times is Charles Reich's "new property, ${ }^{129}$ an application or extension of traditional property principles to the new forms of propertyemployment expectations, welfare and other entitlements provided by the government. Current efforts to expand the Nuremberg War Tribunals and the current War Crimes Tribunal to build an International Criminal Court demonstrate the expansion of an entire legal institution by changing levels of regulation and exposing the difficulties and opportunities of creating legal institutions and laws across jurisdictional domains. ${ }^{130}$

Related to expansion of legal concepts is the common legal creative act of transfer ${ }^{131}$ from one legal domain to another. Another important creative act is the variety of contributions made to legal

128. 410 U.S. 113 (1973).

129. Charles Reich, The New Property, 73 Yale L.J. 733 (1964).

130. In this sense virtually all of international law, both public and private, demonstrates elements of legal creativity in the need to expand, combine and create new legal standards and procedures. Some creativity in this arena will be additive and may get cycled back to domestic legal systems for innovations. In other aspects, international law introduces highly competitive negotiations about rules, procedures and substantive allocations, often based on the relative resources of constituent nations. See, e.g., negotiations that produced the Law of the Sea and the GATT (Lax \& Sebenius, supra note 36); United Nations Convention on the Law of the Sea, U.N. Doc. A/Conf. 62/122 (1982); General Agreement on Tariffs and Trade, Oct. 30, 1947, 61 Stat.5, 55 U.N.T. 187; David Kennedy, When Renewal Reprats: Thinking Against the Box, 32 NYU J. INT'L L. \& PoL. 335 (2000). Note also the United States' resistance to the recent move of the United Nations to establish the International Criminal Court, a move led by Senator Jesse Helms. See Barbara Crosette, U.S. Resists War Crimes Court, N.Y. TIMEs, July 22, 2000 at A-4.

131. Gary Blasi labels this disciplinary or domain "border crossing": "Real innovation in law and lawyering techniques is most often the product of lthe samel crossboundary phenomenon. In some cases, it is the problem that migrates to confront a different kind of lawyer, so that a corporate or personal injury lawyer is asked to consider remedies for the problems that attend slum housing. In other cases, an idea migrates from one region of legal doctrine to another, so that the notion of an implied warranty in the law of sales is imported into landlord and tenant law. In each case it is the novel association of problem and technique, the unusual justaposition of complexity and analytic method, that often produces innovations in both law and lawyering." See Gary Blasi, Teaching/Lawyering as an Intellectual Project, 14 J. LEcil. PROF. 65 (1996). 
scholarship by Joseph Sax-the use of public trust doctrine in environmental law, ${ }^{132}$ the treatment of "slumlordism" as a tort, ${ }^{133}$ both of which were developed by exporting or importing one area of the law to another. This juxtaposition of seemingly unrelated things, or combining, explains much of innovative product development. ${ }^{134}$ Catherine MacKinnon's treatment of pornography as a civil rights or torts claim and the recognition of sexual harassment as employment discrimination $^{135}$ illustrates this important principle-that given a body of law designed to remedy particular harms or wrongs, either the harms or wrongs covered by the law, ${ }^{136}$ or the remedies available, may be extended as we recognize appropriate new members of a category. This type of transfer occurs when we creatively borrow from other domains or systems. Many creative legal theories and institutions actually have their roots in other legal systems (e.g. European social insurance regimes, ${ }^{137}$ civil law models of comparative negligence, and Asian and African systems of dispute resolution). As a method of challenging assumptions, looking at how others of different cultures and domains solve problems ${ }^{138}$ demonstrates how our legal constructs are chosen, not given, and how they may be altered. ${ }^{139}$

132. Joseph Sax, The Public Trust Doctrine in Natural Resources Law: Effective Judicial Intervention, $68 \mathrm{MrCH}$. L. REv. 471 (1970). For a recent additional use of this transfer principle, see Gerald Torres, Who Owns the Sky? Paper presented to Georgetown Environmental Law Seminar, Nov. 5, 1999.

133. See Olin Browder, The Taming of A Duty: The Tort Liability of Landlords, 81 Mich. L. REv. 99 (1982); Joseph Sax, Slumlordism As a Tort, 65 Mich. L. REv. 869 (1967).

134. The military walkie-talkies of World War II were invented by the founder of Motorola who combined what he knew of car radios with wireless communication across battlefields, as he toured Europe on a family trip before the outbreak of the war. See Csikszentmihalyi, supra note 8, at 96-97.

135. Catherine MacKinnon, Feminism Unmodified: Discourses on Life and LAW (1987).

136. Robin West has suggested that tort and criminal law be extended to recognize the now unrecognized claims of women's harms. See West, Caring for Justice, supra note 52.

137. The limited hours of women and child labor legislation defended by the Brandeis-Goldmark brief in Muller v. Oregon, 208 U.S. 412 (1908), were derived from European protective labor laws.

138. For a moving, but painful, illustration of how different cultures define problems and solutions differently, see AnNe Fadiman, The Spirit Catches You and You Fall Down: A Hmong Child, Her American Doctors, and the Collision of Two Cultures (1997).

139. This is not unlike the advice given by Fisher \& Ury and other negotiation theorists that looking to other expert systems is another way to look for creative ideas. How would another discipline characterize or frame a problem and then solve it? For a phenomenological account of problem solving in several different disciplines, see Donald Schon, The Reflective Practitioner: How Professionals Think In ACTION (1983). 
A form of creativity somewhat unique to legal reasoning, though similar to our related linguistic intelligences, ${ }^{140}$ is the process of characterization ${ }^{\mathbf{1 4 1}}$ or argumentation in which we use our words to re-categorize facts, claims, arguments and rules, which disturb the linguistic purity desired by those outside of our domain. ${ }^{142}$ Consider how patent lawyers successfully assimilated the architecture of software to the vocabulary of a machine in order to obtain patent protection for what were thought to be unpatentable "mental processes, abstract intellectual concepts" or ideas. ${ }^{143} \mathrm{Or}$, in a form of creative reversal, consider how conservatives reclaimed takings law to render many land use regulations compensable events under the Fifth Amendment. ${ }^{144}$ In another example, defense counsel who initially resisted plaintiffs' class actions in mass torts captured the device when seeking global settlements with plaintiffs and insurers. ${ }^{145}$

Similarly, alterations (in the form of aggregations or disaggregations) of concepts is a common legal trope, particularly in transactional legal work. Using basic property principles which combine space and time (time bounded estates in land), creative lawyers created co-ops, condominiums and time shares. The development of the corporation, corporate law and corporate financing all demonstrate the highest forms of legal creativity as creative entrepreneurs partner with lawyers to raise capital and create new entities. The "junk bond," the "poison pill," the "golden parachute" and the "Skadden retainer"146 are all legal creations intended to allow, in the view of

140. Howard Gardner has solved the mystery of why so many lawyers write mysteries (and thrillers and novels and memoirs). We are simply shifting within our linguistic intelligence to another domain in which we can use words and language (not to mention logic for mystery writers!)

141. Or rhetoric as the Greeks would have it. For a not so flattering portrait of how we exercise this form of creativity, see Plato, Gorglas (Penguin ed. 1971).

142. See, e.g., George Lakoff, Women, Fire and Dangerous Thungs: What Categories Reveal ABout the Mind (1990).

143. James Gleick, Patently Absurd, N.Y. Trimes MAGazine, March 12, 2000, at 44, 47-48. "Judges and lawyers have devoted millions of words to the nuances lof relevant categories for patent and copyright protections]. Maybe the trajectories of culture, economics and technology have reached a point where a distinction between an idea and machine can no longer be sustained." Id at 48.

144. Lucas v. S.C. Coastal Council, 505 U.S. 1003 (1992); RuchnRd A. EpsteIs, Takings: Private Property and the Power of Eminent Doshin (1985).

145. In re N. Dist. of Cali. Dalkon Shield IUD Prods. Liab. Litig., 693 F.2d 847 (9th Cir. 1982); Amchem Prods v. Windsor, 117 S. Ct. 2231 (1997).

146. A preemptive strike intended to prevent Skadden, Arps, Meagher \& Flom from being retained in an attempt to take over your company. See CAPLAN, supra note 76. 
some, value creation through deals ${ }^{147}$ with creative terms and clauses adapted to meet parties' needs for accumulations of capital and flexibility in governance. Corporate regulators, it must be said, may be equally creative. Disclosure laws and securities regulations were themselves creative responses to the stock market crash of 1929, while current arguments about the importance of a wider group of corporate stakeholders to whom the corporation might be responsible are efforts to create legal relations and liabilities where once there were none. Negotiators in the transactional setting are often particularly good at creating solutions with contingent agreements or gradualist alterations of boilerplate terms. The percentage of gross or net rent (in commercial leasing) or payment (in the performing arts and sports) are alterations of standard rent or salary terms when traditional formulations of fixed amount and distributive bargaining problems gave way to contingent agreements to allocate risk and uncertainty. Similar risk allocation in the litigation context changed conventional monetary judgments to structured settlements and annuities.

Beyond the case or transaction level, legal professionals demonstrate creativity when they create whole new institutions like the "problem solving courts" of drug courts, ${ }^{148}$ vice courts, and integrated family courts that are seeking to work interdisciplinarily with both individuals and families to combine treatment with punishment. Similarly, creative clinical programs in law school have moved from totally litigation-oriented strategies to transactional work, developing venture capital and investments in housing and economic development projects, and multi-disciplinary problem solving, such as legislative advocacy connected to public health professionals for needle exchange programs. ${ }^{149}$

Legal creativity has its own special structure. The adversary system itself may spark certain forms of creativity by requiring reversals and responses to arguments and characterizations of facts. To

147. Ronald J. Gilson, Value Creation by Business Lawyers: Legal Skills and Asset Pricing, 94 YALE L.J. 239 (1984).

148. Michael Dorf \& Charles Sabel, Drug Treatment Courts and Emergent Experimentalist Government, 53 VAND. L. REv. 831 (2000); Judith Kaye, Changing Courts in Changing Times: The Need for a Fresh Look at How Courts are Run, 48 HAstings L.J. 851 (1997).

149. Scott Burris, HIV Education and the Law: A Critical Review, 20 L. MED. \& Health Care 377 (1992); Scott Burris et al, Syringe Exchange in Pennsylvania: A Legal Analysis, 8 Temp. Pol. \& Crv. RTs. L. Rev. 41 (1998). See also Temple Law School's "Legal Advocacy for Patients" Clinical Program. 
respond is to think and to deny as well as to explain. Thus, new explanations must be found, new defenses created, and new causes of action and new transactional forms to be discovered. Some adversarial creativity may be exercised in the spirit of law avoidance. The decision of Buckley $v$. Valeo ${ }^{150}$ and its attempts to sustain limits on campaign contributions produced the legally creative Political Action Committee (PAC), a cure that some think is worse than the original problem. Recall that Howard Gardner warns that intelligences have no morality and can be exercised for good or ill. ${ }^{151}$ Law's creativity may be somewhat limited by the bounds of law and legal ethics rules, but there still remains a fair amount of problem space to be manipulated within our adversarial culture. At the same time, the adversarial culture may also constrain and cabin our thinking unnecessarily by structuring it in polarized and oppositional terms. Are transactional lawyers more creative by being less constrained? Corporations and trusts, for example, were created legally to accomplish many different goals, some adversarial (tax delay, minimization or avoidance), but also to permit different power and control arrangements and to bundle and unbundle interests of wealth, time and assets to permit great flexibility of action.

While this essay does not exhaustively examine all possible forms of legal creativity, it is useful to map the kinds of legal ideas that have been developed onto the kinds of creative thinking processes and multiple intelligences that might be applied to legal problem solving. Our intellectual and cognitive frames can be stretched, even by a mechanical application of different modes of thinking or different points of entry. ${ }^{152}$ At least more explicit attention to how we think alone and reason together might demonstrate more paths of legal cognition. Legal creativity is necessarily limited by its need to work within the law, or at least within the foreseeable boundaries of legal change, but for optimal problem solving it would seem we should try to push the boundaries of little "c" creativity as much as we can to produce at least a greater number of choices about how best to accomplish legal results.

In searching for big " $\mathrm{C}$ " creativity in law, beyond perhaps the group act of drafting the Constitution, we should consider the contributions of legal scholars to the development of overarching theories or legal frameworks that attempt to reorient the development of law.

150. 424 U.S. 1 (1976).

151. Gardner, INTELLigence Reframed, supra note 68, at 66-77.

152. For example, mathematical and quantitative assessments for division, suggested by Brans \& Taylor, supra note 32 . 
One cannot avoid the remarkable achievement of Richard Posner and the law and economics movement in creating a legal meme that has been quite powerful in its transmission into the legal culture and law (with so many of its proponents now on the bench). Additionally, how can we ignore the legal memes created by Christopher Columbus Langdell as we generally labor in both the same physical and intellectual architecture that he created over one hundred years ago? Legal realism, critical legal studies, legal feminism and critical race theory are all group acts of legal creativity, seeking to develop new frames for thinking about legal problems, creating theories, new causes of action and new remedial schemes. What Weber called charismatic leadership demonstrates another form of creativity-intellectual or motivational leadership to rethink existing paradigms, ${ }^{153}$ evident in both intellectual and political realms. For examples of how particularly creative lawyers develop their legal strategies and consider both the formation and the utilization of their ideas, several recent biographies of important legal thinkers are instructive, ${ }^{154}$ along with detailed case studies of strategies in particular litigation or other legal events. ${ }^{155}$ Those of us who are laboring on the concept of problem solving or constructive lawyering ${ }^{156}$ hope that we have launched another legal meme-that of the problem solving ${ }^{157}$ lawyer and the integrative, interest-based negotiator. Whether we succeed depends on

153. Gardner describes the particular kinds of intelligences that political and organizational leaders are likely to have. GARDNER, INTELligence REFRAMED, supra note 68, at 116-34 (linguistic, intrapersonal and interpersonal intelligences). He defines leaders as those "people who can change the thoughts, feelings and/or behaviors of a significant number of other people." Id. at 126.

154. See, e.g., Gerald Gunther, Learned Hand: The Man and the Judge (1994); William Harbaugh, Lawyer's Lawyer: The life of John W. Davis (1973); Arthur Kinoy: Rights on Trial: The Odyssey of a People's Lawyer (1983); John Noonan, Persons and Masks of the Law: Cardozo, Holmes, Jefferson, and Wythe as Mak. ers of Masks (1976); Mark Tushnet, Making Civil Rights Law: Thurgood MarSHALL AND THE SUPREME COURT (1994).

155. See, e.g., Jonathan Harr, A Civil Action (1995); Anthony Lewis, Gideon's Trumpet (1964); Anthony Lewis, Make No Law: The Story of N.Y. Times vs. Sullivan (1991); Gerald Stern, The Buffalo Creek Disaster (1976) (all chronicling creative ideas for lawsuits, arguments, and legal strategies).

156. See Center for Public Resources-Institute for Dispute Resolution Problem Solving and Legal Education Project Report, presented at Symposium on Dispute Resolution and the Problem Solving Lawyer, Harvard Law School, April 7-8, 2000.

157. "Problem solving" is clearly the educational buzz word of the decade. Every major university and liberal arts college is touting its goals to create a "problem solving curriculum," see, for example, Penn Arts \& Sciences, University of Pennsylvania Newsletter, Winter 2000, at http://www.collegeupenn.edu/newsletter/mar00/abc.htm (Last Visited April 6, 2000). One class offered to undergraduates is GH 210, Seminar in Faculty-Student Collaborative Learning: Developing an Interdisciplinary ProblemSolving Curriculum Focused on West Philadelphia. 
what creative ideas we can offer for legal education and it is to that agenda that I now turn.

\section{Implications for AND Applications to Legal Education}

If the teachings of the fields of creativity and multiple intelligences are to be effectively applied and transferred to legal education we must re-examine how we do things. Although analysis and traditional legal reasoning are important ${ }^{158}$ and should not be removed from the curriculum, it is important to understand the consequences of such education. Legal analysis does teach close readings of texts and teaches judgment by putting students in the role of the detached critical reader. But analysis, as taught in legal education, is often more critical than the more constructive forms of reasoning and analysis that are taught in some graduate schools and in business schools. Perhaps it is our adversarial frame, ${ }^{159}$ but we teach analysis by critical correction, critique and oppositional culture. ${ }^{160}$ I suggest that explicitly teaching creativity with positive examples, models, experiences of empowerment and accomplishment may make better problem solvers out of our students than the current legal education culture permits. While we need to know and understand the biased and inaccurate heuristics we often employ, it is also important to develop some positive heuristics in the context of legal problem solving. This article concludes with some concrete suggestions below.

At the level of conventional case instruction, it is possible to teach alternative ways of structuring and solving legal problems at the same time that students are learning to brief a case, make arguments and discover the relevant facts and holding. As described elsewhere, ${ }^{161}$ a series of questions could be asked of students of each case

158. Every modern critique of the profession and legal education seems to begin with the statement that we just need supplementation, not a totally new system. See CPR Commission on Lawyering, Problem Solving and Legal Education, at http:/l www.cpradr.org (last visited February 18, 2001); ANTHONY T. KRONunN, THE LOST Lawyer: The Fatuing Idpals of the Legal Profession (1993); Brest and Krieger, supra note 5.

159. Why wouldn't the adversarial and competitive economic frame similarly affect business schools? Perhaps because the entrepreneurial culture also values creativity and the creation of new products?

160. See Deborah Tannen, The Argument Culture (1998); Carrie MlenkelMeadow, The Trouble with the Adversary System in a Post-Modern, Multi-cultural World, 38 WM. \& Mary L: Rev. 5 (1996).

161. Carrie Menkel-Meadow, Taking Problem Solving Pedagogy Seriously: A Response to the Attorney General, 49 J. LEGAL Educ. 14 (1999); Carrie Menkel-Meadow, To Solve Problems, Not Make Them: Integrating ADR in the Law School Curriculum, 46 SMU L. REv. 1995 (1993). 
read to encourage creative thinking. This would push students to look for multiple possibilities and directions that the case could have taken, before it hardened into its appellate form. In addition to the stated facts and legal issues, one should ask the following questions:

What are the "real" issues between the parties?

What were the parties trying to accomplish?

Who else is, or was, involved in the transaction, dispute or underlying issue?

How else might the parties have dealt with or managed their problem aside from the lawsuit at hand?

What other solutions, proposals or resolutions of their matter would have been possible?

Answering these questions allows students to see how much more might be at stake than what the court fixes on; that other people may be involved and that other resources might have been mobilized to deal with the problem. Such readings of cases open up other possible readings of a case, perhaps to "creative misreadings" and to other possible solutions. ${ }^{162}$ I often ask students to re-think a case or problem for new possibilities after they have worked on some of the brainteasers or other problems described above. This might be a good empirical testing ground of the effectiveness of creativity teaching and training-can students or lawyers see more possibilities in legal problems after they have had the opportunity to use some other intelligences? ${ }^{163}$

In all courses, experiences of successfully creating some legal product, such as a contract, a complaint, a deed, a will, a motion or a single jury instruction, will empower students to feel they have begun to learn to create legal products. Borrowing from Howard Gardner's "processfolio,"164 law students might actually keep on going files of

162. At an early stage of my negotiation course, I ask students to select 5 cases at random from a reporter, a casebook or now, the computer, and to answer these questions. Together we explore the different kinds of processes and resolutions that might have been used to solve problems that traveled up the litigation food chain to appellate treatment.

163. This issue of the "transferability" from one domain or one intelligence to another is both an interesting theoretical problem and one that greatly affects educational theory and practice. See Brook Baker, Beyond MacCrate: The Role of Context, Experience, Theory and Reflection in Ecological Learning, 36 ARIz. L. REv. 287, 291 (1994); See also Steven Friedland, How We Teach: A Survey of Teaching Techniques in American Law Schools. 20 SeatTle U. L. Rev. 1 (1996).

164. Howard Gardner, Multiple Intelligences: The Theory in Practice 225 26 (1993). 
their written drafts and re-writes throughout law school to document the process and progress in their own thinking. ${ }^{165}$

A few law schools, like Northwestern, have experimented with involving students with actual or simulated clients in the first year, by having them participate in an initial interview, consider what the client's problem(s) might be and then, to begin to consider solutions and learn how to do legal research from the context of a real case. This might increase student motivation and focus to begin some work on an actual legal problem while beginning to develop some knowledge of substantive law (of course, with proper supervision). Starting some client contact early in legal education might be important not only for focus and motivation, but as a way of encouraging the development of skills and knowledge in at least two other intelligences which are clearly important in legal problem solving-interpersonal and intrapersonal. ${ }^{166}$ Where actual client contact is not possible, structured simulation courses, ranging from simple in-class exercises $^{167}$ to a simulated complex litigation problem, offer students the possibility of trying to create solutions to problems and to live with choices made in on-going rounds of a case or problem. Many law schools have begun using business school-like complex case studies and simulations to place problem-solving in richer and dynamically changing fact contexts, while also teaching responsibility for decision making by using rounds of choices and behaviors in which choices made at one stage carry over to another. ${ }^{168}$

165. The processfolio that documents change is in contrast to the portfolio, where only the best is chosen and fails to document the thinking process itself. For teachers of negotiation that use journals (I do not), which require students to reflect on what they have learned, this is an equivalent use of a processfolio idea.

166. Many negotiation courses now use various methods to focus on interpersonal skills such as use of the Thomas-Kilman Conflict MODE exercise, Myers-Briggs and the Harvard Interpersonal Skills Exercise. Legal interviewing and counseling courses have also long used insights from Rogerian therapy to teach skills of active listening. Decision theory has been incorporated in many schools' teaching of legal counseling, Brest \& Krieger, supra note 5. For my argument that the human side of lawyering is essential to any full conception of legal education, see Carrie MenkelMeadow, Narrowing the Gap by Narrowing the Field; What's Missing From the MacCrate Report-Of Skills, Legal Science and Being a Human Being, 69 Wasu. L. Rev. 593 (1994).

167. See Leonard Riskin \& James E. Westbrook, Dispute Resolution and Law. YERS TEacher's ManuAL (2d ed. 1998).

168. Clinicians, of course, have used contextually rich cases for problem solving for close to thirty years. Some problems use real clients or dynamically changing facts to simulate as much as possible the conditions of the real world, see BINDER, supra note 42. 
In my ideal world of education, multiple intelligences would be taught simultaneously. Substantive courses taught at the same time as skills courses would hone cognitive, writing, interpersonal, intrapersonal and problem solving skills. Students might choose to specialize in this modern world in which domain specific knowledge is complex, but also ever-changing. An organized program of education would build on sequences of knowledge acquisition and skills development to be practiced in thought, writing, simulations and then in the real world (in the "thinking in action"169 that characterizes good clinical education). Once again, applying Howard Gardner's educational models for primary and secondary education, ${ }^{170}$ law students might learn both more deeply and more broadly by being engaged in multiple intelligence projects. Whether for the full three years or some portion of the legal curriculum, students could be assigned to research a particular issue, or a community, local, state, corporate or national problem, work with or intern with individuals involved in that problem and develop a legal plan or strategy for dealing with it. ${ }^{171}$ Imagine that instead of a third year research or writing project, a law student would be required instead to demonstrate problem solving skills with a project processfolio or some performance of understanding.

Legal intelligences can be systematically taught and evaluated. ${ }^{172}$ Howard Gardner actually suggests that interpersonal skills could be evaluated by watching a student attempt to resolve a dispute with a store clerk or manage a difficult committee meeting, in what he calls "assessment in context."173 Since problems that are

169. Donald Schoen, Educating the Reflective Practitioner (1987); Donald Schoen, The Reflective Practitioner (1983).

170. Gardner, Multiple Intelligences, supra note 164, at 65-158.

171. Many specialized seminars in law schools now do this-some focused on specific community or legal issues, like economic development, homelessness, public health, public interest strategies, complex litigation.

172. The MacCrate report is such an effort to develop a list of legal intelligences. See Legal Education and Professional Development-An Educational ContinuUm, Report of the Task Force on Law Schools and the Profession: Narrowing THE GAP (1992). This is a start, but I have criticized the report as being too focused on ends-means, litigation thinking. See Menkel-Meadow, Narrowing the Gap by Narrowing the Field supra note 166.

173. Gardner, Multiple InTElligences, supra note 164 , at 176 . How many of us legal educators would do well in such an evaluation? To the extent that dispute resolution education is expanding to include not only dyadic negotiation skills, but multiparty and multi-cultural and international negotiations, as well as consensus building like processes (reg-neg), there will be many more sites for "assessments in context." 
solved in the real world are not neatly packaged in course-titled categories, problem solving in context calls on students not only to solve problems, but to name and frame them as well.

Framing the intellectual and educational problem to be solved is very important in transforming legal education into a truly problem solving enterprise. As an example, consider a problem from the Goldberg, Sander \& Rogers Dispute Resolution text. ${ }^{174}$ In Colonial Confectioners, Inc., ${ }^{175}$ an elderly man seeks to sell his candy-making factory and hopes the business will be continued by the purchaser. The potential purchaser wants to tear down the factory and build a more profitable office building. In the problem as written, both sides have damaging confidential facts that the teacher's manual tells us will kill the deal if they are revealed.176 The purpose of the exercise is for students to confront their truth telling practices and the role of deception in negotiation. However, when I have used this problem after class creativity exercises, students carefully reveal the "damaging" information and work around it to create very interesting solutions to the problem. 177 Thus, the curriculum's frame around a set of problems or courses can strongly influence how students choose to use the material. Using the framing effects, changing the focus with the same problems over time illustrates how problems can change or that they have many different issues. ${ }^{178}$

Gardner suggests using different "entry points" for the study of particular problems, which demonstrate that there are, in fact, many epistemologies to be used in unpacking legal problems. ${ }^{179}$ These include the use of narrative (a deeply contextualized story of the facts); a logically based deductive version of the situation; a foundationalterminological approach (what is at issue here for the parties, for the larger society?); aesthetic understandings-(organizational charts, a

174. Stephen Goldberg, Frank Sander \& Nancy Rogers, Dispute Resolution: Negotiation, Mediation and Other Processes (3d ed. 1999).

175. Id. at 106.

176. Both the fact of the purchaser's true interest and a rumor of an eminent domain action on the property are unknown to the respective sides.

177. These have included ESOPs for the candy factory employees, a historically preserved front of the building, with a candy shop/factory on the first floor of a multiuse office building, and a host of other solutions that take account of both parties' preferences.

178. Some business school case studies, for example, are "framed" by the course title as marketing, finance, accounting, or human relations problems. More complex problems require students to consider many issues simultaneously. Ethics problems, for example, are almost always embedded in the larger context and more complicated facts of the problem.

179. Gardner, Intelligence Reframed, supra note 68, at 169-72. 
map of a transaction or deal); and experiential or field knowledge. ${ }^{180}$ The educational key to problem solving here is to make the problems richer than they often appear in casebooks, and even the most conventional cases can be approached with more variety in the questions posed and the particular issues to be solved.

Even while contextualizing a problem, however, the law teacher must remain vigilant about the limits of the law. We can ask how can law help resolve a problem, but must also ask how the law constrains what the parties seek to do. When rules of disclosure or substantive values draw lines around party choices, students learn that we do not inhabit a totally laissez-faire world. Though Howard Gardner does not acknowledge morality as a separate intelligence, law students can learn that each intelligence or each solution to a problem must be evaluated and must satisfy at least legal, if not moral, standards. ${ }^{181}$ Solutions, must be explained, justified, tested against other solutions and explored for their legal limits, as well as for Pareto-optimality. Not all legal problems will have creative solutions.

Finally, we should confront the "points of entry" for education in problem solving and creativity. I think there are at least three locations to worry about. First, it is not sufficient to treat legal problem solving and creativity as bounded subjects, appropriate only in negotiation or dispute resolution courses. Even more than ethics, ${ }^{182}$ problem solving and creativity should be taught pervasively throughout the curriculum. We need new textbooks, many more case studies, and different ways of dividing up the curriculum. These are big curriculum reform projects and are unlikely to happen in many, if any, law schools. Yet, some short forms of professional development seminars for law teachers and the creation of new teaching materials and problem sets could bring us a long way toward re-orienting the way legal reasoning is taught in law schools, even in conventional class rooms.

180. Even in my simulated negotiation problems, students are encouraged to "check facts" in the real world, so they gather estimates from real roofers, mortgage rates from banks, stock prices, "going rates" for plea bargains, and actual time to trial in the jurisdiction.

181. Concrete problem solving is also a good place to observe the positive law-morality debate in jurisprudence. See H.L.A. Hart, The ConCEPT OF LAw (1961); LoN Fuller, The Morality of LaW (1964).

182. See Deborah Rhode, Professional Responsibility: Ethics by the Perva. sive Method (1994); Carrie Menkel-Meadow \& Richard Sander, The "Infusion" Method at UCLA Teaching Ethics Pervasively, 58 LAw \& CoNTEMP. ProBs. 129 (1995). 
Second, we may need to rethink the relative emphasis of litigation to other forms of legal problem solving in our curricula. ${ }^{183}$ Increased emphasis on transactions, deals, raising capital for a variety of entrepreneurial and public interest activities, document drafting, as well as organizational planning and design skills may be necessary for our students who will be lawyers in this new century. If cases come to trial in less than $5 \%$ of all cases (even if a large number still begin in litigation) it is clear that our educational emphasis is mis-matched to what our students will face in the workplace. While we are responsible for creating a firm intellectual background which is still regarded as "timeless" for lawyers who must adapt to many substantive domains, shouldn't the content of that intellectual domain respond to the world in which our students will practice their craft?

Third, and finally, we still consider legal problem solving mostly an individual enterprise. Our students write papers and take tests alone but we hope they work in study groups and share teams and partnerships in clinics and occasionally in classroom exercises. Real world problem solving, however, involves multi-party, multi-issue, multi-jurisdictional and multi-cultural inputs, and lawyers are increasingly working in more complex groups of individuals who may come from a variety of different domains. Working collaboratively (rather than exclusively competitively or cooperatively, in that false dichotomy of the negotiation literature) is an important element of legal problem solving. It is not just the interpersonal skill of facilitating and managing meetings, negotiation sessions and consensus building processes, all of which are important and should be taught in modern law schools. If creative solutions to legal problems are to be arrived at, we must acknowledge the multiple approaches to problems that different people bring and what we can learn from working with many different people. We can improve the analysis, as well as the design, of solutions to legal problems if we can learn more things from more people.

183. At the conclusion of several focus groups with practicing lawyers at Georgetown, which is part of our curriculum review project, we have learned that recent graduates feel that they are ill prepared for lawyering tasks and decision making that do not involve conventional litigation choices or matters. Both younger lavyers and more experienced lawyers want our graduates to be able to make decisions (often in nano seconds), or draft documents in organizational (both public interest and entrepreneurial) settings for which they are not prepared by our standard curriculum and its steady diet of litigated cases. 
To summarize, at the institutional or curricular level, this article suggests the following alternative program structure for teaching legal creativity and effective problem solving:

First Year: Instead of a repetitive diet of common law courses to focus on case-based analogical reasoning, the first year should introduce students to a variety of forms of legal reasoning and intelligences, including common law (perhaps contracts and torts as the classic courses), statutory drafting and interpretation, Constitutional law as formative of institutions and a place to consider both history and deep legal and political theory and jurisprudence, some introduction to another discipline (quantitative analysis or narrative interpretation) and some exposure to a real world legal problem (an interview with an individual client, exposure to an entity or institutional issue through some internship) and some exposure to the now multiple intelligences of legal research (book and computer based logic and searches), as well as some introductory work on the interpersonal aspect of legal counseling and advising. Ideally, there would still be room in the first year curriculum for some subject totally removed from obvious relations to law-an architecture, engineering or social work course in problem solving, a literature or language course or even a visual arts course (in which there would be some explicit attention paid to how such a discipline might inform legal issues).

Second Year: In addition to continuing and deepening the study of some area of substantive law (some depth of knowledge to experience a sense of subject matter competence, to pursue domain-based expertise and understand the history of problem solving in a particular area), we should add a variety of skills building blocks (question framing, useful in interviewing, litigation practice, meeting management, fact gathering; negotiation and multi-party coordination and collaboration, drafting and planning exercises) and some substantive building blocks (accounting, economics, some sociology and psychology related to law and legal institutions) and a simulation-based course on problem solving in a particular area, with law, dynamic facts and the need to find relevant information and decision makers to assist in problem definition, solutions and implementation. In the second year, every student would have to complete a major project of some kind, in collaboration with other students. The project itself could vary from a research paper, a drafted document, a transaction planned or some other solution to a legal or social problem. ${ }^{184}$ (This

184. This past year a group of Georgetown law students completed the legal and political process to found a charter school in Washington DC that will focus on law and legal issues for high school students. The school will open in the next academic 
would give each law student a legal "processfolio" as a representation of a concrete work product completed while in law school).

Third Year: In the final year of law school ${ }^{185}$ students would deepen one field of substantive expertise, take related courses in both the law school and other graduate departments (business school, public health, social work), enroll in one problem solving seminar that would require the students to jointly plan some response to a legal or social problem (that actually exists, as opposed to the second year simulation experience), enroll in some clinical or field (internship or observational) experience that attempts to relate legal theory to practice and to complete some kind of "graduation" project (either individually or alone). The third year also would be a place for at least one course outside of the domain of law for students to explore other modes of problem solving. In an ideal educational environment, law students would interact with other graduate students (business students or medical students as clients in planning or litigation matters), both to share what is particular about legal problem solving and law, and to learn to function with other domain trained professionals and possible clients. Also, one should require some form of professional responsibility or ethics training, perhaps again as an exercise in comparative ethical reasoning.

This problem solving curriculum is designed to increase the multi-disciplinary nature of law training and clearly some will think it is too thin on the mastery of doctrine or legal theory. Yet, as the modern world demonstrates a growing dependence on multi-disciplinary solutions to complex problems in the environment, in international relations, in domestic social welfare, education and housing, it seems that the best way to teach creativity and skill in problem solving is to broaden both the subject matter and the processes which we use to teach legal problem solving. For law students to experience some mastery and sense of accomplishment as they learn their craft and subject matter material, seems an improvement over the simple steady diet of the same case method that has informed legal education for so long.

year. The students began work on this project through their own commitment and a clinical course and completed it with assistance from each other, some professors and other relevant community advisors.

185. For the purpose of this exercise I have left lav school in its current form of three years but ideally, legal training would take four years; the third year would be a Northeastern-Antioch like full year of legal internship in the vorld, with a final return year in school for students to pursue more academically and with professorial supervision answers to both substantive and processual issues that arose during the field work year. 
Whether creativity and problem solving can effectively be taught, along with legal doctrine and rigorous policy analysis, and whether such a curriculum also can teach decision making and judgment, important qualities for the practicing lawyer remains to be tested. Whether such an alternative curriculum realistically can be negotiated in today's legal education environment requires some very creative thinking and action. 